\title{
Following The Positions of Parsing According to Grammarians
}

\author{
Nassif Jassim Muhammad Al-Rawi \\ Department of Arabic language, College of Education-Al-Qaim, University of Anbar, Iraq \\ naseef.jaseam@uoanbar.edu.iq
}

\begin{abstract}
:
It dealt with the issue of following the positions of parsing according to grammarians, and the various grammatical disagreements in that. The first prompt: I dealt with the backup copies, and I took the backup copies in it. As for the fourth topic, it dealt with the subject of the name not negating gender and the opinions and differences between grammarians in it. concluded my study with the most important results of the research and a list of sources and references. Praise be to Allah, the Cherisher and Sustainer of the worlds.
\end{abstract}

Keywords: Following; Positions; Grammarian; Opinion; Linguistic.

Crossref doi https://doi.org/10.51345/.v31i2.331.g168 


\section{الاتباع على المحل عند النحويين \\ أ.م.د. نصيف جاسم محمد الراوي \\ قسم اللغة العربية، كلية التربية- القائم، جامعة الأنبار، العراق \\ naseef.jaseam@uoanbar.edu.iq}

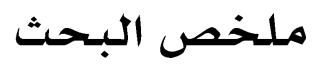

تناول البحث مسألة الاتباع على المحل عند النحويين، وما فيها من خلاف نحوي متنوع ، وقد جاء البحث على أربعة مباحث: لمبحث الأول: تناولت فيه تابع المضاف إلى المصدر، والاراء النحوية في هذه المسألة ، المبحث الثاني: تناولت فيه تابع المنادى المبني، وما فيه من خلاف بين النحويين، المبحث الثالث : تناولت فيه الاتباع على عحل اسم إنّ. أما المبحث الرابع: فكان فتناولت فيه تابع اسم لا النافية للجنس، وما فيه من آراء وخلافات بين النحويين. وختمت دراستي بأهم النتائج التي توصل اليها البحث وبقائمة للمصادر والمر اجع، والحمد لله رب العالمين. 


\section{المقدمة}

\section{أو لاًَ: الإتباع لغة:}

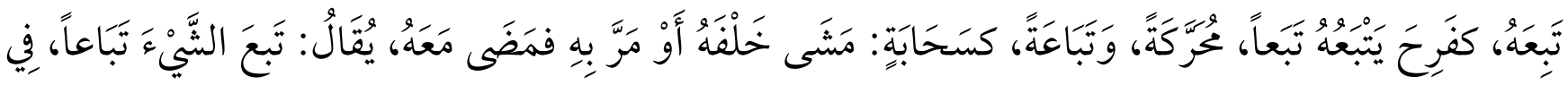

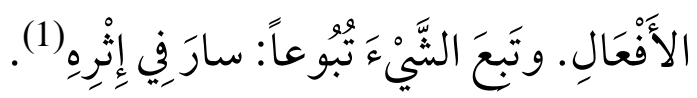

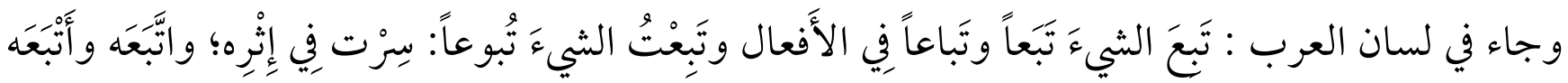

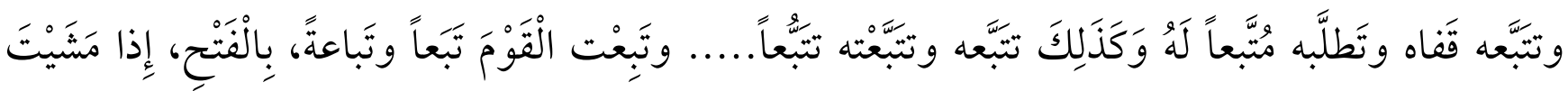

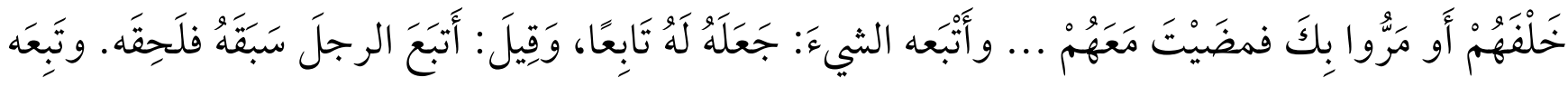

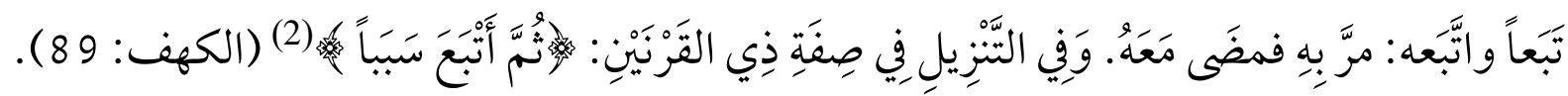

\section{ثانيًاً : الاتباع اصطلاحا : الصاع}

أما الاتباع اصطلاحا فقد عرفه ابن يعيش بقوله: ((التَّوابع هي الثواني المُساوِيَُّ للأوّل في الإعراب بمُشارَكتها له في العوامل، ومعنَى قولنا: ثَوانِ، أي: فُروعُ في استحقاق الإعراب، لأنّهم لمُ تكن المقصودَ، وإنَّما هي من

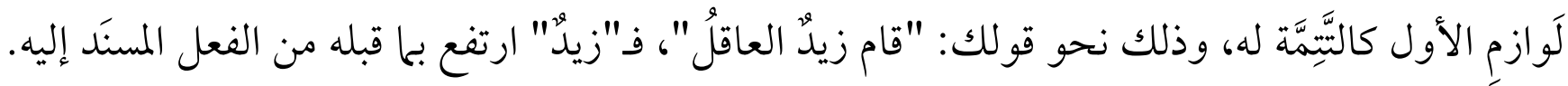
و"العاقلٌ" ارتفع بها قبله أيضًا من حيثُ كان تابعًا لزيد كالتَّكمِلَة له، إذ الإسنادُ إنّما كان إلى الاسم في حالِ وصفه، فكانا لذلك اسمًا واحدًا في الحكم)(3). قال ابن الحاجب: ((التوابع: كل ثان أعرب بإعراب سابقه من جهة واحدة))(4). وعرفه الرضي بقوله: (( كل ثان أعرب بإعراب سابقه لأجله، أي إعراب الثاني لأجل إعراب الأول))(5). ويعرفه الشريف الجرجاني بقوله: ((التابع: هو كل ثانِ بإعراب سابقه من جهة واحدة))(6). فالتبعية عند النحويين مرتبطة بالعامل فهو يتبع ما قبله بحسب عامله رفعا ونصبا وجرا وهو خمسة أضرب: تأكيد، وصفة، وبدل، وعطف بيان، وعطف نسق. 


\section{المبحث الأول: تابع المضاف إلى المصلدر للمصدر المضاف خمسة أحوال:}

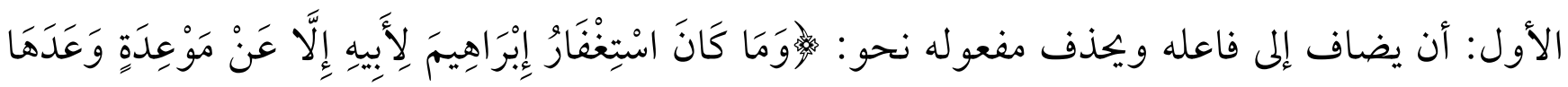

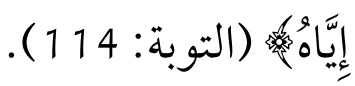

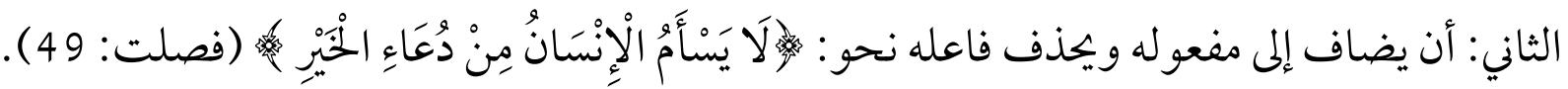

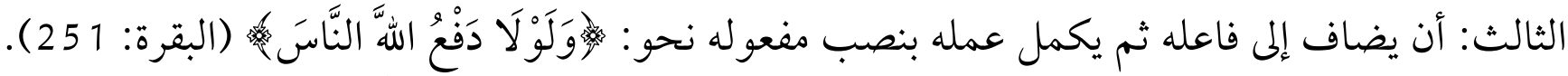
الرابع: أن يضاف إلى مفعوله ثم يكمل عمله برفع فاعله نحو قوله عليه الصلاة والسلام: (وحجج الْبَتِِ مَنِ

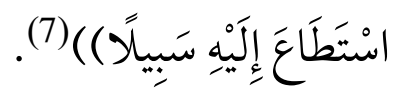

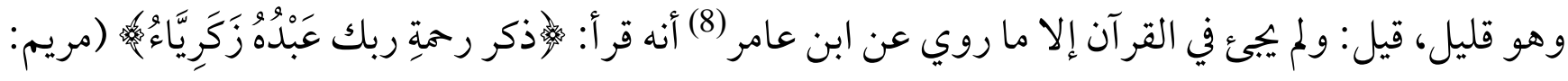
2) -برفع الدال والهمزة- وليس ذلك خصوصا بالضرورة على الصحيح. والأكثر في المصدر إذا أضيف إلى مفعوله أن يحذف فاعله (9). الخامس: أن يضاف إلى الظرفأفيرفع وينصب كالمنون نحو: "عجبت من انتظار يوم الجمعة زيدُ عمرًا" (10) وما يهمنا هنا تابع المضاف إلى المصدر اذيقول ابن مالك(11): وجُر ما يتبع ما جُر ومن راعى في الاتباع المحل فحسن فهو يجيز هنا الاتباع على اللفظ والاتباع على المحل المضاف إليه المصدر، إن كان فعلا فمحله رفع، وإن كان مفعولا فهو في موضع نصب، إن قدر المصدر بأن وفعل الفاعل، وفي موضع رفع إن قدر المصدر بأن وفعل المفعول، خلافا لمن منع تقديره بفعل المفعول. فيجوز في التابع الجر على اللفظ والرفع على المحل، إن كان فاعلا أو نائبه، والنصب على المحل إن كان مفعولا به، تقول: "عجبت من أكل الخبز واللحم ، فيجوز في (اللحم) الجر والرفع والنصب. فالجر على اللفظ، والنصب على المحل؛ لأنه مفعول به، والرفع على تقدير: إن أُكل الخبز واللحم (12) 
وظاهر كلام ابن مالك جواز الإتباع على المحل في جميع التوابع، وهو مذهب الكوفيين، وطائفة من البصريين، وذهب سيبويه(13) ومن وافقه من أهل البصرة إلى أنه لا يجوز الإتباع على المحل، وفصل أبو عمرو فأجاز في العطف والبدل ومنع في التوكيد والنعت، والظاهر الجواز لورود السماع، والتأويل خلاف الظاهر (14). ومن ذلك قول الشاعر (15):

\section{حتّى تَهَجَّرَ في الرواحِ وهاجَها}

وفي الشاهد رفع المظلوم الواقع صفة لـ"المعقب" المجرور لفظا بإضافة المصدر "طلب"، ولكنه مرفوع محلا؛ لأنه فاعل للمصدر؛ فتبعته الصفة بالرفع نظرا إلى المحل (16) . فرفع "المظلوم" على الإتباع لمحل المعقب ومن شو اهد النصب قول الشاعر (17):

\section{قد كنت داينت بها حسانا خافة الإفلاس و الليانا}

عطف "الليانا" بالنصب على الإفلاس المجرور لفظا بإضافة المصدر "يخافة"؛ لكونه أي -المعطوف عليهمنصوب محلا؛ لأنه مفعول للمصدر (18). وييجوز أن نعرب "الليانا": مفعو لا معه، ويكون معطوفا على "خخافة" على حذف مضاف ومن شواهد الرفع قول الشاعر (19): السالك الثغرة اليقظان سالكها مشي الهلولِ عليها الخيعل الفضلُ "الفضل" جعله مرفوعًا لمنعوته "الهلوك" باعتبار محله لأنه فاعل بالمصدر (20). فمذهب الكوفيين وبعض البصرين جواز الاتباع على المحل، ومذهب سيبويه والجمهور منع الإتباع على المحل وما جاء من ذلك مؤول.

ويرى المرادي أن الظاهر الجواز لكثرة الشواهد على ذلك، والتأويل على خلاف الظاهر (21). يقول ابن مالك: ((ويتبع بجروره لفظا، ومحلا،، ما لم يمنع مانع، فإن كان مفعولا، ليس بعده مرفوع بالمصدر جاز في تابعه الرّفع، و النّصب، والجرّ)()(22). 
ويذكر ناظر الجيش أن المجرور بالمصدر إمّا مرفوع الموضع، وإما منصوب الموضع فلك في التابع من نعت أو معطوف وغيرهما أن تجره، حملا على اللفظ، وهو الأجود، ولك أن ترفعه حملا على الموضع؛؛ إن كان المجرور مرفوع الموضع، وأن تنصبه إن كان المجرور منصوب الموضع، فأما الجر فمستغن عن شاهد (23).

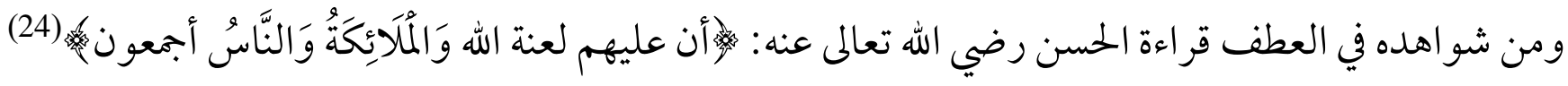
(آل عمران: 87)، بالرفع، وتقديرها: أولئك جزاؤهم أن يلعنهم الله ويلعنهم الملائكة، ويلعنهم الناس لهن

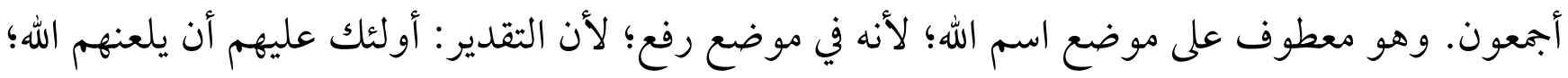
لأنه مصدر أضيف إلى الفاعل (25).

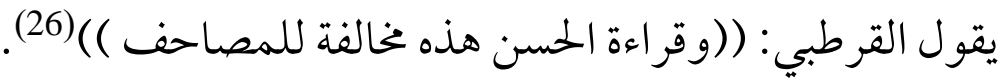

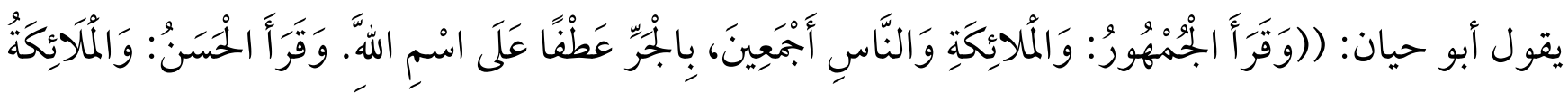

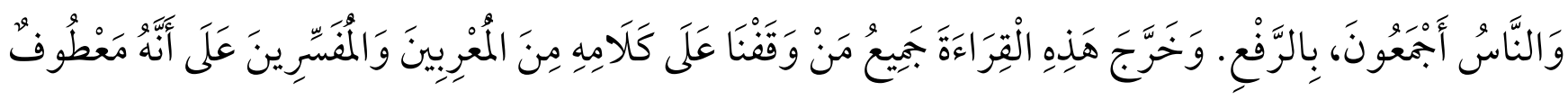

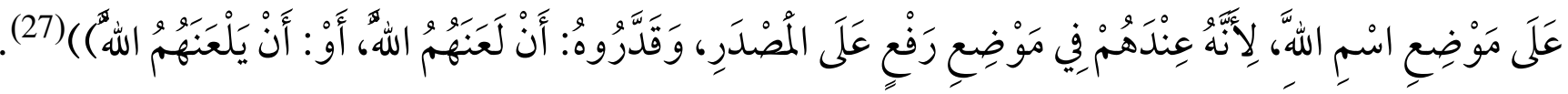

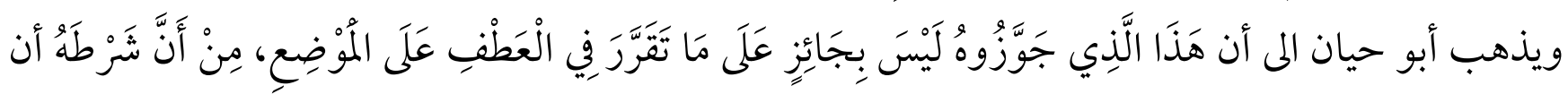

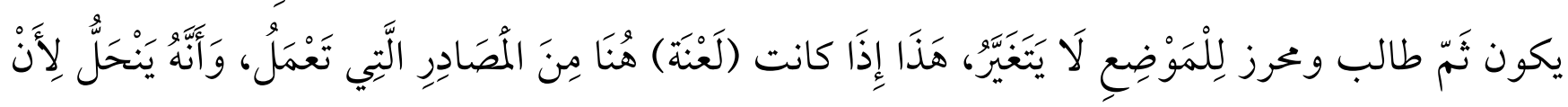

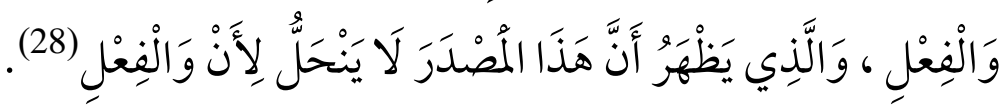

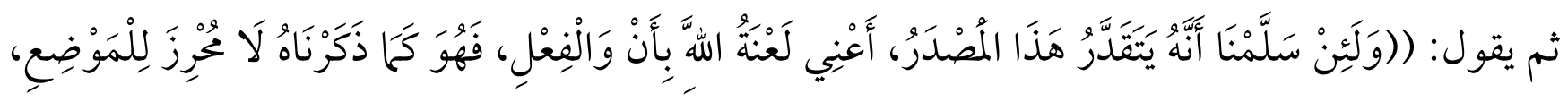

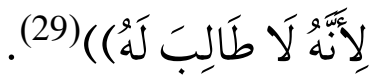
فأبو حيان لا يجيز التقدير الذي قدره المفسرون والمعربون ،وذكر أبو حيان توجيهات أخرى لقراءة الحسن

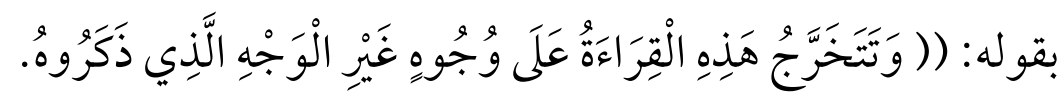

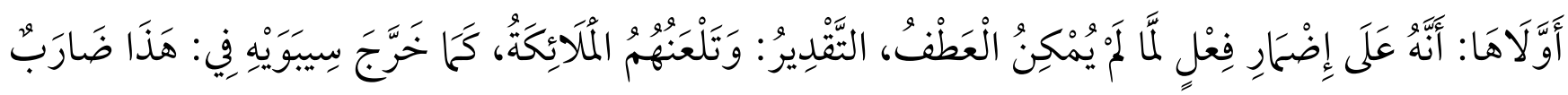

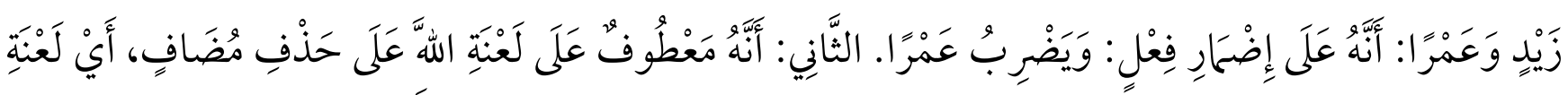




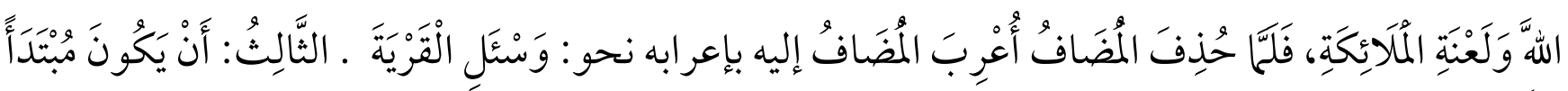

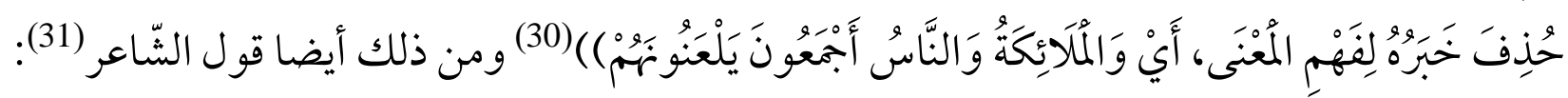

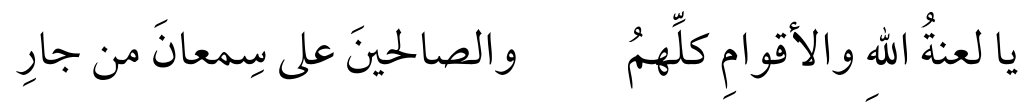

وقد استشهد سيبويه بهذا البيت على حذف المنادى بعد (يا) من اللفظ، وهو مقدر في المعنى، ورفع (لعنة) بالابتداء، و(على سمعانَ) خبره. وتقدير الكلام: يا قوم، لعنة اللهُ والأقوام23. يا لغير اللعنة ولو كان واقعا عليها لنصبها لأنه نداء مضاف.

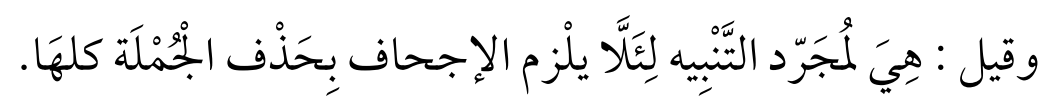

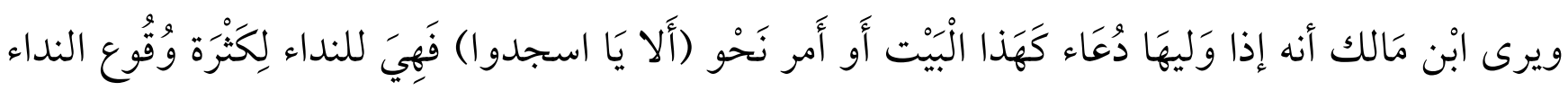

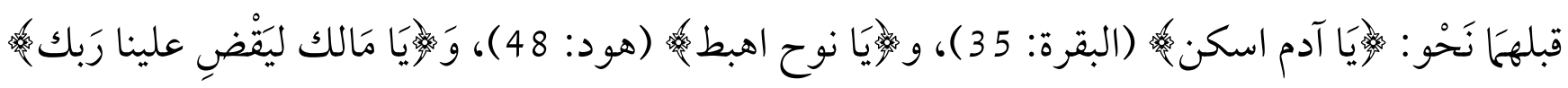

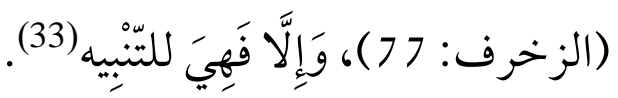

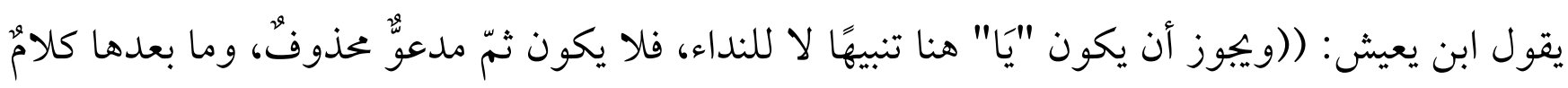

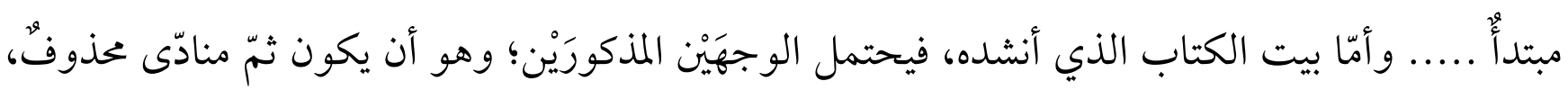

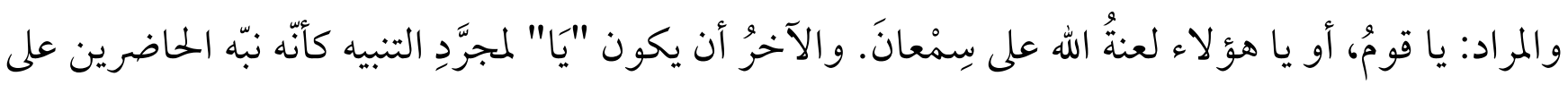
سبيل الاستعطاف لاستماع دُعائه، و"اللعنة" رفعُ بالابتداء، و"على سمعان" الخبرُ. ولو كانت "اللعنة" مناداةً لنَصبها، لأنَها مضافة )(34)، وأمّا النصب فمن شو اهده في النّعت قول الرّاجز (35): ما جعل امر أ لقوم سيّدا إلّال اعتياد الخلق الممجّدا نصب (الممجدا) نعتا لـ(الخلق) على المحل؛ لأنّ (الخلق) بجرور لفظا بالإضافة، منصوب محلّا بالمصدر (اعتياد)، ومن شو اهده في العطف قول الشاعر (36):

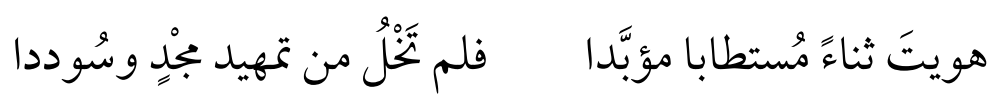
نصب (سؤددا) بالعطف على محل (بجد) لأنه مفعول مضاف للمصدر (تمهيد) وييجوز أن يكون على تقدير: ومهدت سؤددا 
وجعل ابن مالك في قوله: ((ما لم يمنع مانع)) قيدا في الحمل على اللفظ خاصة، وكأنه احترز به من نحو: يعجبني إكرام زيد وأنت عمرا، وأكره ضرب زيد وإياك عمرو؛ فإنّ الإتباع على اللفظ يتقدر في المثالين. ويرى ناظر الجيش أنّ المصنف لا يعتبر المحرز في مراعاة الموضع، ولذلك أجاز الإتباع على المحلّ ههنا، وأما من يعتبر المحرز فلايجوز (37). وفي مراعاة المحلّ، في هذا الباب ثلاثة مذاهب: أحدها: مذهب سيبويه، والمحققين، من البصريين، أنّه لا يجوز (38) الثاني: مذهب الكوفيين، وجماعة من البصريين: أنّه يجوز، إلا أن الكوفيين في الإتباع على محل المفعول المجرور يلتزمون ذكر الفاعل، ولا يجيزون حذفه، فيقولون: عجبت من شرب الماء واللبن زيد(39). الثّالث: مذهب أبي عمرو الجرمي، وهو التفصيل، فأجاز ذلك في العطف، والبدل، ومنعه في النعت، والتوكيد، وحجّته أنّ العطف والبدل عنده من جملة أخرى، فالعامل في الثاني غير العامل في الأول، وأما النعت، والتو كيد، فالعامل فيها واحد وهما شيء واحد ومحال أن يكون الشيء بجرورا مرفوعا، أو بجرورا منصوبا(40). وظاهر ما ورد عن العرب جواز الإتباع على المحل، ويحتاج مانع ذلك إلى تأويل، وقد تؤول على إضمار عامل في العطف، رافع أو ناصب . وأمّا في النّعت فإنّ بعضهم تأول الرفع في (الفضل) على أنه على الجوار في قول الشاعر: السالك الثغرة اليقضان(41)... كالخفض في: هذا حجر ضبّ خرب . وأما النصب في البيت وهو: إلّا اعتياد الخلق الممجّدال(42). فيمكن أن يكون بفعل مقدّر، ولا شكّ أنّ التأويل خلاف الأصل، -ما لم يقصد. قال ابن مالك: ونبهت بقولي: ((فإن كان مفعولا ليس بعده مرفوع بالمصدر))(43) على جواز ثلاثة أوجه، في تابع المجرور، من نحو: عرفت تطليق المرأة، فلك في نعت المرأة، والمعطوف الجرّ على اللفظ، والنصب على تقدير المصدر بفعل الفاعل، والرفع على تقديره بفعل ما لم يسم فاعله (44). 
وفي الحديث أن النبي (صلى الله عليه وسلم) : أمر بقتل الأبتر وذو الطفيتين (45)، على تقدير : أمر بأن يقتل الأبتر وذو الطُّيتين (46).

يقول أبو حيان: (وقوله ومحلا يعني أنه إن كان المضاف إليه المصدر فاعلاً رفعت التابع، أو مفعولاً نصبت التابع، وإن اعتقدت في المصدر أنه يضاف إلى المفعول الذي لم يسم فاعله - وهو مذهب المصنف - رفعت التابع أيضاً، فتقول: يعجبني اكل زيد الظريف الخبز، ويعجبني شرب اللبن الصرف زيد، ويعجبني ركوب الفرس المسرع، وكذلك في باقي التوابع. وظاهر كلام المصنف جواز مراعاة المحل في جميع التو ابع)(47). ومذهب سيبويه مبني على أن الحمل على الموضع إنما يكون حيث محرز الموضع لا يتغير عند التصريح بالموضع، وهنا لو صرحت برفع الفاعل أو نصب المفعول لتغير العامل بزيادة تنوين فيه. وأما مذهب الكوفيين ومن وافقهم من البصريين فاستدلوا على ذلك بقراءة الحسن البصري التي مرّ ذكرها والتو جيهات فيها(48).

ومن جوز الإتباع على المحل من البصريين فالاختيار عندهم الحمل على اللفظ، وأما الكوفيون فكذلك إن لم يفصل بين التابع والمتبوع بشيء، فإن فصل اعتدل عندهم الحمل على اللفظ والحمل على الموضع، نحو: يعجبني ضرب زيد عمرو وبكراً، بنصب بكر وخفضه، وقيامك في الدار نفسك ونفسك، بالجر والرفع على حد سواء في الجودة(49). هذا ما لم يكن المفعول المضاف إليه المصدر ضميراً، فالعطف على الموضع، ولا يجوز على الخفض إلا في ضرورة الشعر، نحو: يعجبني إكرامك زيد وعمراً، بنصب عمرو خاصة، وكذلك: يسرني جلوسك عندنا وأخوك (50). ويرى الفراء أن: عجبت من ضرب عبد الله ومحمد - مستكره، ويجوز في الشعر. وكذا النعت و التوكيد عنده، فإن فرقت حسن عنده، فقلت: عجبت من ضرب عبد الله زيداً ومحمد. وقال هشام نحوه، إلا أنه لم يقل: يجوز في الشعر، فكأنه جائز عنده في الشعر وفي غيره. وقوله ما لم يمنع مانع احتراز من نحو: عرفت قربك، فإنه لابد في العطف عليه من إعادة المضاف (51). 
والذي أراه في هذه المسألة هو جواز الاتباع على اللفظ وعلى المحل وذلك لكثرة الشو اهد الشعرية والثرية في هذا الباب وهو أولى من التأويل .

\section{المبـحث الثاني : تابع المنادى المبني}

تابع المنادى المعرب يجب نصبه ويكون تابعا للفظ المنادى إن كان تابعه نعتا أو عطف بيان أو تو كيدا ، أما تابع المنادى المبني فيأتي على أقسام عدة : أحدها: ما يجب نصبه مراعاة لمحل المنادى؛ وهو ما اجتمع فيه أمران: أحدها: أن يكون نعتا أو بيانا أو توكيد|(52) بشرط ألا يكون المنادى اسم إشارة، ولا كلمة "أي"، أو (أية)

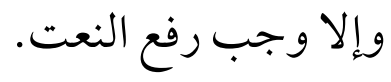
ثانيها: أن يكون مضافا مجردا من "أل"، فالنعت نحو : يا زيد صاحب عمرو. والبيان نحو : يا زيدُ أبا عبد الله (53)، و التوكيد نحو: يا تميم كلهم أو كلكم. وحكي عن جماعة من الكوفيين منهم الكسائي والفر اء والطوال جواز رفع المضاف من نعت وتوكيد، وتبعهم ابن الأنباري فأجازوا : يا زيلُ صاحبُنا(54).

وذكر المرادي أن الصحيح المنع لأن اضافته محضة(55) وأجاز الفراء رفع التوكيد والمنسوق المضافين، قياسا على النعت (56).

فما نصب منه فعلى الأصل، وما رفع فلشبه متبو عه بمرفوع في اطر اد الهيئة.

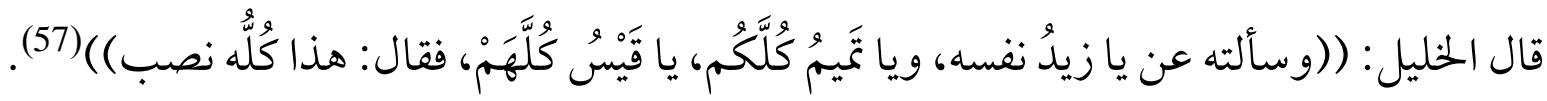

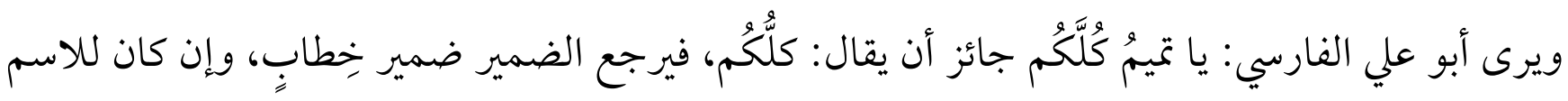
الغائب، لأن هذا الغائب وقع موقع خِطابٍ، وبناؤه أيضًا كذلك (58). ولا يرفع إلا وهو مفرد، أو مضاف يشبه المفرد لكون إضافته غير مخضة نحو: يا زيد الحسن الوجه. 
وقد منع الأخفش مراعاة المحل وقال: وأما قولهم: يا تميم كلكم، فإن رفعوه فهو مبتدأ وخبره محذوف، أي: كلكم مدعو، وإن نصبوه فبفعل محذوف اي: كلكم دعوت(59). ويرى ابن مالك أن لأصالة نصب التابع في هذا الباب فضلاً على الرفع بأن اشترك معه في التابع المفرد والشبيه به، وخص بالتابع المضاف إضافة محضة (60). يقول ابن مالك(61):

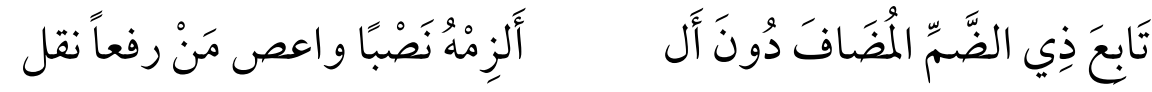

وقوله: (واعص مَنْ رفعاً نقل) يشير فيه إلى ما يراه أبو بكر بن الأنباري من جواز رفع صفة المضموم إذا كانت مضافة، وإلى ما روى ابن خالويه من أن الأخفش حكى : يا زيد بنُ عمرو بضم النون، فهذا من الشاذ الذي لا يلتفت إليه، و لا يعرج عليه (62).

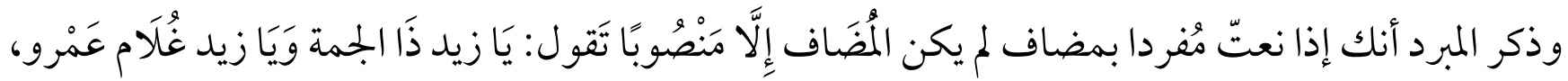

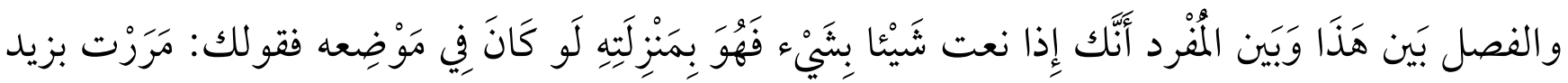

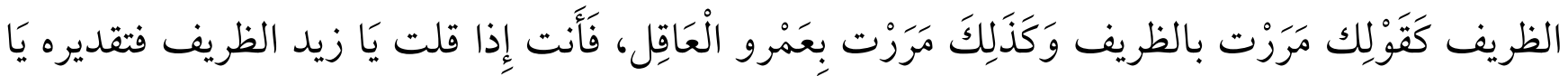

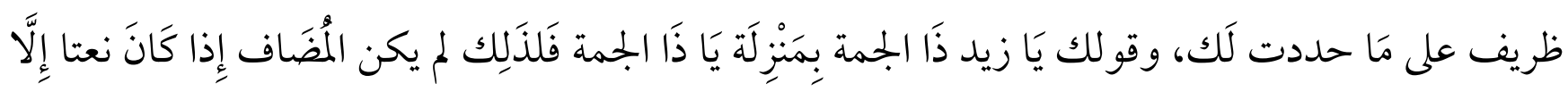
نصبا(63).

وذهب ابن يعيش الى أنه لا ييوز رفعُ هذه الصفة بحالٍ، لأنّ المنادى إذا وُصف بالمضاف لم يكن فيه إلّا النصبُ، وذلك من قِبَلِ أنّ الصفة من تَّام الموصوف، لأنها خخصِّصةٌ للموصوف موضِحةٌ له، كتخصيصِ الألف واللام في نحوِ: "الرجل"، و"الغلام". ولذلك لا يجيوز تقديمُها عليه(64). وإذ كانت منزلتُها من الموصوف هذه المنزلةَ، جاز أنّ يُعتبر فيها من الحكىم ما يُعتبر فيه، فكلا لم يكن في المنادى إذا كان مضافًا إلا النصبُ، نحو : "يا غلامَ زيد"، كذلك لا يكون في صفِة المنادى إذا كانت مضافةً غيرُه (65). و الثاني: ما يجب رفعه مراعاة للفظ المنادى؛ وهو نعت (أيّ) و(أيّة). ونعت اسم الإشارة؛ إذا كان اسم

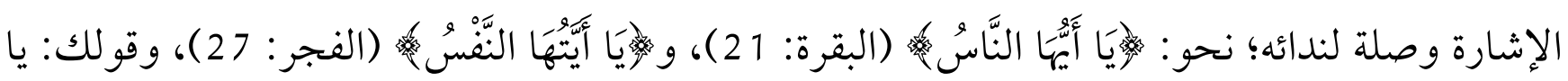


هذا الرجل، وإنها جاز الرفع مراعاة للفظ مع أن المتبوع مبني، لأنه مشبه للمعرب في حدوث ضمه بسبب الداخل عليه (66).

والثالث: ما يجوز رفعه ونصبه؛ فالنصب إتباعًا لمحل المنادى، والرفع على تشبيه لفظ المنادى بالمرفوع تنزيلا لحركة البناء العارضة بسبب دخول حرف النداء منزلة حركة الإعر اب بسبب دخول العامل ـ ومقتضى ذلك أن يكون حرف النداء هو الر افع للتابع بناء على أن العامل في التابع هو العامل في المتبوع في غير البدل، والقول إن الرافع التبعية قول ضعيف لا يجسن التخريج عليه(67). وخر جه الأزهري بقوله: ((في المنادى المضموم أن يكون نائب فاعل في المعنى والتقدير : مدعو زيد، فرفع تابعه بالحمل على ذلك)(68) وهو نوعان: أحدها: النعت المضاف المقرون بـ"أل" بـ نحو: يا زيدُ الحســـنَّ الوجه. و الثاني: ما كان مفردا من نعت، أو بيان، أو تو كيد، أو كان معطوفا مقرونا بـ"أل"؛ نحو: "يا زيد الحسنُ" و"الحسنَ"، و"يا غلام بشر"، و"بشر ا"، و"يا تميم أجمعون"، و"أجمعين"، وقال الله تعالى: وَيَا جِبَالُ أَوَبِي مَعَهُ

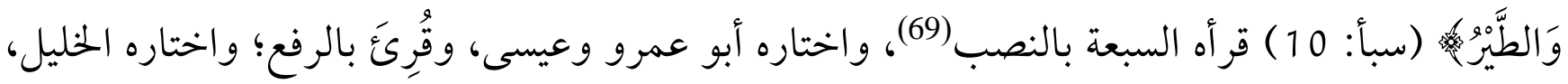

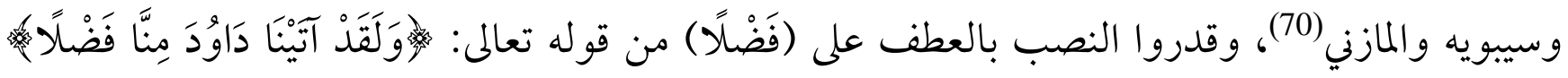
(سبأ: 10 )، ويذهب المبرد الى أنه إن كانت (أل) للتعريف مثلها في (الطير)؛ فالمختار النصب، أو لغيره مثلها في (اليسع): فالمختار الرفع (71). فقراءة الرفع في (الطير) بالعطف على لفظ الجبال، وقراءة النصب فيها عطفا على محل الجبال؛ أو عطفا على (فضلا). وقد ذكر ابن مالك وناظر الجيش أن المبرد فرّق بين ما أثرت الألف واللام فيه كالرجل وبين ما لم تؤثر فيه كالحارث فيرجح النصب على الرفع في نحو: الرجل لشبهه بالمضاف في تأثيره بـا اتصل به، ويرجح الرفع على النصب في نحو: الحارث لشبهه بالمجرد في عدم التأثر (72). 
ولمُ أعثر على هذا التفصيل للمبرد بل نجده يجّزّ الوجهين فيقول: ((وكلا الْقَوْلَنِنِ حسن وَالنّصب عِنْدِي حسن على قِرَاءَة النَّاس)(73) (73).

وزعم الكوفيون أن النصب في (العاقل) من (يا زيد العاقل)، ليس على الموضع وأن العرب أرادت نداء النعت، فلما لم يدخله النداء نصبته، وإن كان وصفًا موطئًا نحو: يا زيد زيد الطويل، فلك الحمل على الموضع نصبًا، وهو أرجح، نص عليه سيبويه، ولك الحمل على اللفظ، ورجحه أبو عمرو، وكلاهما مسموع عن العرب، ويجوز فيه القطع إما على إخبار، وإما على نداء. والأصمعي يوجب القطع، فإن كان التابع بدلاً مفردًا نكرة نصبته ونونته نحو: يازيد رجلا (74).

وزعم الأخفش أن تابع النكرة المقصودة من النعت، والتوكيد لا ييجوز فيه إلا الرفع، فتقول: يا رجل العاقل ويا رجال أجمعون، وزعم أيضًا في الأشهر من قوليه أن الاسم العلم المبني على الضم لا ييوز في نعته إلا النصب على الموضع، ولا يتبع على اللفظ أصلاً، وأن الحركة في (يا زيد) العاقل بالضم حركة اتباع لا حركة رفع (75)

وتظهر ثمرة الخلاف في النعت المضاف بعد النعت المفرد، فعلى مذهب الأخفش: يا زيد العاقل ذا الجمة، لا يكون في (ذا الجمةة) إلا النصب كان نعتًا للمنادى، أو نعتًا للعاقل، ويفصل على مذهب الجمهور، فإن كان ذو الجمة نعتًا للعاقل رفعت، وإن كان نعتًا للمنادى نصبت. ومن النحويين من يعتقد بناء الصفة إذا رفعت في نحو: يا زيد الطويل، لأن حركتها كحركة المنادى(76)، وهو رأي يخالف ما عليه جمهور النحويين من أن حق تابع المبني أن يكون تابعا لمحله . ويذهب الأزهري إلى أن وجه اختيار الرفع مشاكلة الحركة وحكاية سيبويه أنه أكثر (77). والرابع: ما يعطى تابعًا ما يستحقه إذا كان منادى مستقلا؛ وهو البدل و المنسوق المجرد من (أل)؛ وذلك لأن البدل في نية تكرار العامل، والعاطف كالنائب عن العامل؛ تقول: "يا زيدُ بِشْرُ" بالضم، وكذلك "يا زيدُ وِشُُْ" "، وتقول: يا زيد أبا عبد الله، وكذلك: يا زيد و أبا عبد الله، وهكذا حكمهها مع المنادى المنصوب(78). 
هذا هو مذهب الجمهور وقد نص عليه سيبويه والمبرد(79) وأجاز الكوفيون والمازني النصب في النسق. و أشار

$$
\text { ابن مالك في شرح التسهيل إلى تقويته (80). }
$$

يقول ابن مالك: ((وأجاز المازني والكوفيون إجراء المنسوق العاري من أل مجرى المقرون بها، فيقولون: يازيد

وعمر اوعمرو، كما يقال بإجماع: يازيد والحارثُ والحارثَ ()(81).

وقد أيد ابن مالك هذا الر أي فذكر أنه غير بعيد من الصحة إذا لم تنو إعادة حرف النداء، فإن المتكلم قد يقصد إيقاع نداء واحد على الاسمين، كما يقصد تشريكها في عامل واحد نحو : حسبت زيدا وعمرا حاضرين، وكأن

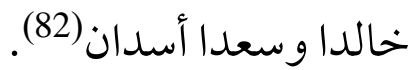

وقد جوز ابن مالك وجهين للبدل: الوجه الأول أن يجعل فيها كمستقل وهو الكثير، ومنه قولنا: يا غلام زيدُ. و الثاني: يعطى فيها الرفع والنصب لشبهه فيها بالتو كيد والنعت وعطف البيان وعطف النسق المقرون بأل (83.

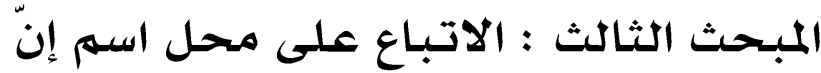

إذا عطفت استًا على (أنّ) وما عملت فيه من اسم وخبر فلك أن تنصبه على الإِّر اك بينه وبين ما عملت فيه (أنّ) ولك أن ترفع أحمله على الابتداء، أي -على موضع أنّ- فتقول: إن زيدًا منطلق وعمرًا وعمرواُ لأن

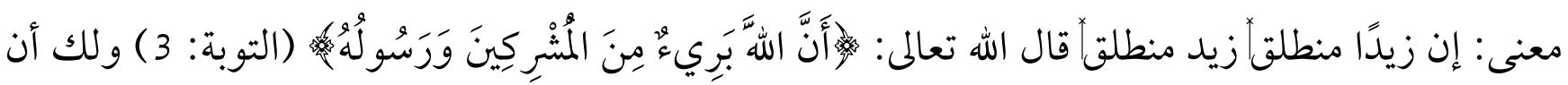
تحمله على الاسم المضمر في "منطلق" وذلك ضعيف إلا أن تأتي "هو " توكيدًا للمضمر فتقول: إن زيدًا منطلق هو وعمرو، وإن شئت حملت الكلام على الأول فقلت: إن زيدًا منطلق وعمرًا ظريف(84). وذكر ذلك سيبويه في باب ما يكون محمولا على (إنّ) أنه يرتفع على وجهين: وجه حسن وآخر ضعيف، فأما الوجه الحسن فأن يكون محمو لا على الابتداء، لأن معنى إن زيدا منطلقّ وعمرو، زيدٌ منطلق وعمرو، واما الوجه الآخر الضعيف فأن يكون محمولا على الاسم المضمَر في المنطلق، ويمكن تحسين هذا الوجه بتقدير (هو) فنقول: إن زيدا ظريفُ هو وعمرو، وإن شئت جعلت الكام على الأول فقلت: إن زيدا منطلقّ

$$
\text { وعمر|(85)، ومن ذلك قول الشاعر (86): }
$$




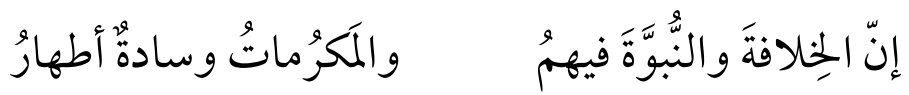

برفع المكرمات وسادة عطفا على محل (الخلافة). وفيه وجه آخر ضعيف وهو عطفه على ما في الخبر من الضمير. ولكن تشايع (إنّ) في ذلك دون سائر أخواتها(87). يقول السيرافي: ((فأما حمل المعطوف على الابتداء فهو كلام جيد قويّ، وذلك أنّا لو جئنا بمبتدأ وخبر بعد اسم إنّ وخبره وجعلنا جملة معطوفة على جملة لكان كلاما جيدا لا ضعف فيه كقولنا: إن زيدا مقيم، وعمرو خارج، كأننا قلنا زيد خارج وعمرو مقيم، فإذا كان خبر أحدهما مثل خبر الآخر اكتفي بأحد الخبرين، كقولنا زيد مقيم وعمرو، وإن زيدا مقيم وعمرو، فيعلم أن خبر الثاني مثل خبر الأول ويطرح اكتفاء بالأول)(88). يذكر ابن مالك في شرح التسهيل أن نصب المعطوف على اسم إنّ مستغن عن التنبيه عليه، لأنه كالعطف على سائر المعمولات. ولا فرق في ذلك بين إن وأخواتها، ولا بين وقوعه قبل الخبر ووقوعه بعده ، أما الذي لا يستغنى عن التنبيه و التوضيح فهو رفع المعطوف ، ويكون على ضربين : أحدهما مشترك فيه، وهو العطف على الضمير المرفوع بالخبر ، و الثاني العطف على معنى الابتداء، وهو عند البصريين خخصوص بإنّ ولكن، ومشروط بتحام الجملة قبله (89)، و منه قول الشاعر (90): فمن يكُ لم ينجب أبوه و أمُهّ فإنّ لنا الأمَّ النجيبةَ والأبُ ومثاله مع لكن قول الآخر (91):

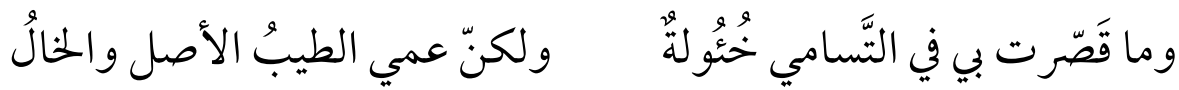

ويرى ابن مالك أن هذا العطف المشار إليه ليس من عطف المفردات كما ظن بعضهم، بل هو من عطف الجمل، ولذلك لم يستعمل إلا بعد تمام الجملة، أو تقدير تمامها، ولو كان من عطف المفردات لكان وقوعه قبل التحام أولى، لأن وصل المعطوف بالمعطوف عليه أجود من فصله. ولو كان من عطف المفردات لجاز رفع غيره من التوابع (92). 
وقد اختلف النحويون في وجه هذا العطف اختلافًا كثيرا، فمنهم من جعل ذلك عطفًا حقيقةً، من باب عطف

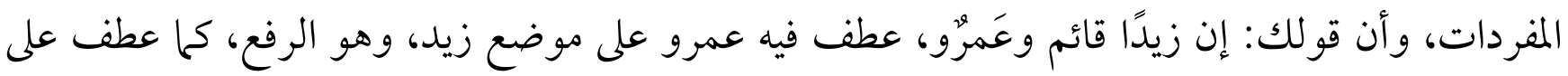
موضع خبر ليس في نحو:

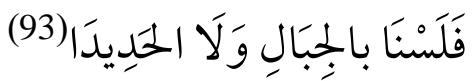

وإليه ذهب الشلوبين وابن أبى الربيع ، ونقل عن الأخفش، والفراء، والمبرد، وابن السراج، والفارسيّ أن العطف هو عطف الجمل وليس عطف المفردات (94).

والذي يظهر لي أن العطف هو عطف مفردات لا عطف جمل والدليل على ذلك في حالة النصب، فنقول: إن

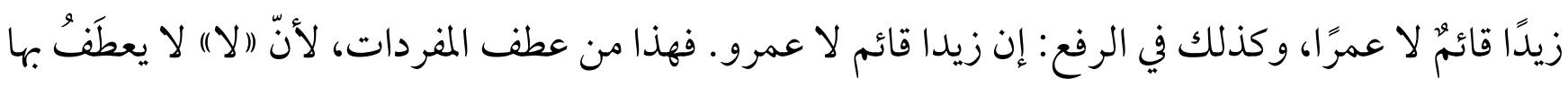

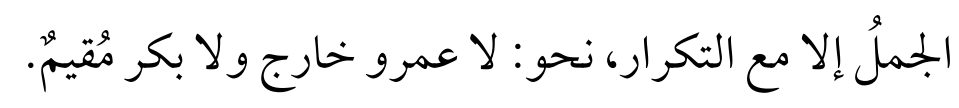

وذهب ابن مالك الى أن (إنّ ولكنّ) لا يتغير بدخولهم) معنى الجمملة فجاز أن يعطف بعد بعد مصحوبيها مبتدأ

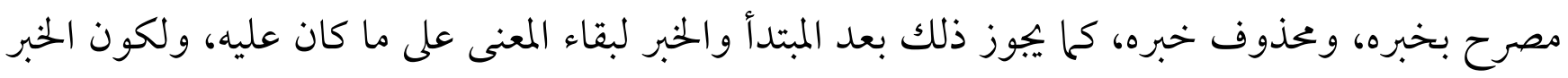

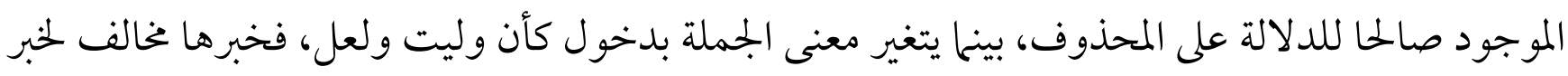
المبتدأ المجرد، فلا يغني أحدهما عن الآخر (95). ويرى ابن مالك أن مثل (إنّ ولكنّ) في رفع المعطوف على معنى الابتداء (أنّ) إذا تقدمها عِلْم أو معناه، فمعنى

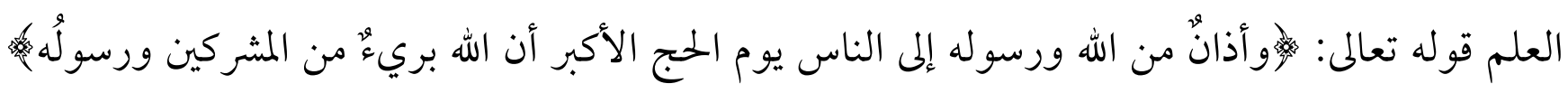
(التوبة: 3). وما سبق بالعلم قول بشر بن خزام الاسدي(96):

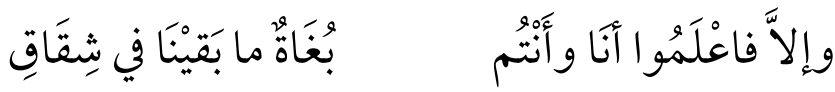
وقد سوى سيبويه بين (إنّ) و(أنّ) وقدّر الشاهد: فاعلموا أنا بغاة وأنتم كذلك، محله على التقديم والتأخير (97). 


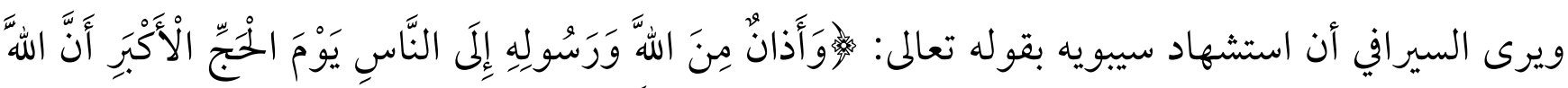

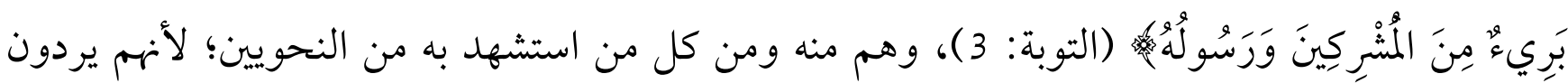

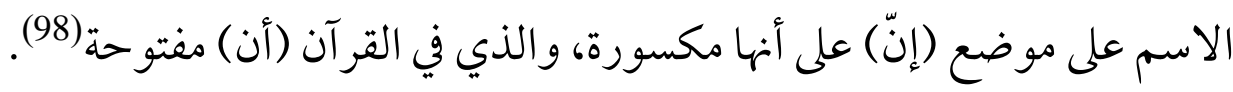

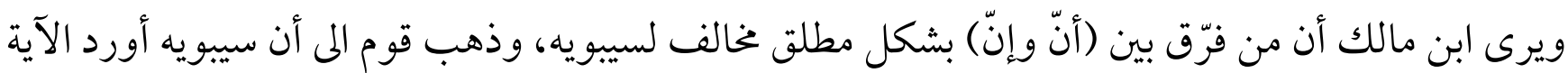
على قراءة الحسن بكسر الهمزة (99). ويظهر لي أن سيبويه سوّى بين المكسورة الهمزة و المفتوحة ولم يفرق بينها فنجده قد استثى (لعل وكأن وليت)

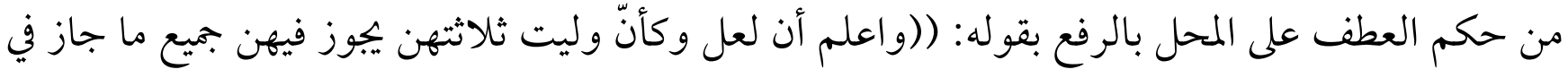

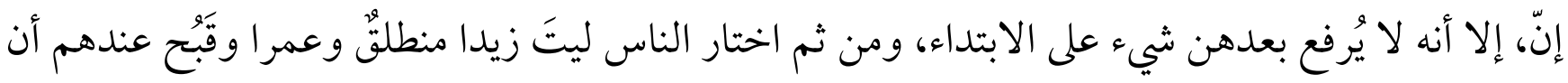
يمملوا عمرا على المضمر حتى يقولوا هو، ولم تكن ليت واجبة ولا لعل ولا كأن، فقبح عندهم أن يُدخلوا

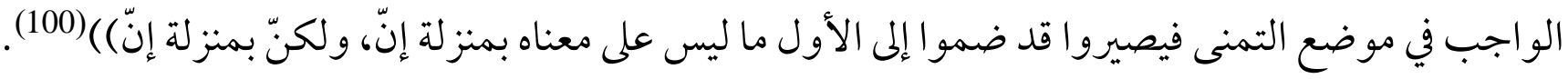

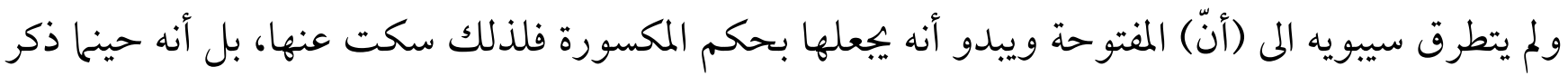
الأمثلة للمكسورة قال: (( وفي القرآن مثله )(101) واستدل بالاية الكريمة: وأن الله بري من المشركين

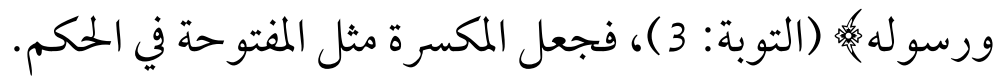
ونقل السيرافي عن المبرد اعتراضا على سيبويه في قوله: و (لكنّ) المثقلة في جميع الكلام بمنزلة (إنّ) ، فقال: نحن ندخل اللام في خبر (إنّ) ولا ندخلها في خبر (لكن). وقد ردّ السيرافي على المبرد بقوله: ((والذي أراده سيبويه أن (لكن) بمنزلة (إن) في العطف الذي ساق الكلام عليه. وسياقه للككلام يدل على إرادته )(102). وما نسبه السيرافي للمبرد ليس دقيقا، فبعد الرجوع الى كتب المبرد نجده يتابع سيبويه في هذه المسألة بقوله:

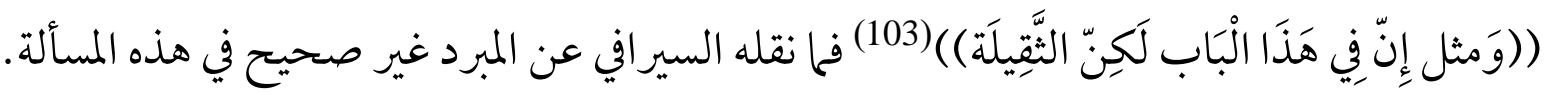
وذكر ابن يعيش أن من النحويين من لم يمز العطف على موضع "لكنّ"، ويدّعي زوالَ معنى الابتداء، لإفادة

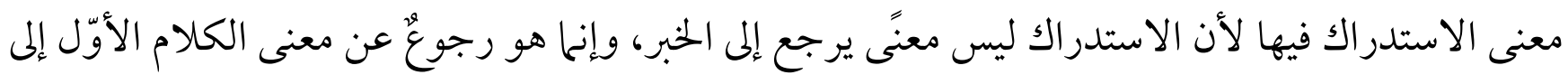
كلام آخر، و تدارُكُه. وذلك أمرُ لا يتعلّق بالخبر (104). 
وقد اختلف النحويون في جواز العطف قبل الخبر، فأجاز الكسائي رفع المعطوف بعد إن قبل الخبر مطلقا، فيقول: إن زيدا وعمروّ قائمان، وإنك وزيدٌ ذاهبان. ووافقه الفراء إن خفي إعراب الاسم نحو: إنك وزيدُ

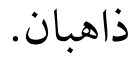

وقد ضعف ابن مالك هذين الرأيين بقوله: ((وكلا المذهبين ضعيف، لأن إنّ وأخواتها، فكم) امتنع بكان أن يكون للجزأين إعراب في المحل يخالف إعراب اللفظ يمتنع بإنّ، ولو جاز أن يكون اسم إن مرفوع المحل باعتبار عروض العامل، لجاز أن يكون خبر كان مرفوع المحل بذلك، ولا اعتبار لتساويها في أصالة الرفع وعروض النصب، ولا حجة لهما فيما حكى سيبويه من قول بعض العرب: إنهم أجمعون ذاهبون، وإنك وزيد ذاهبان)(105)

وأجاز الفر اء في المعطوف على اسم غير إن ما أجاز في المعطوف على اسم إن، واستشهد بقول الراجز (106):

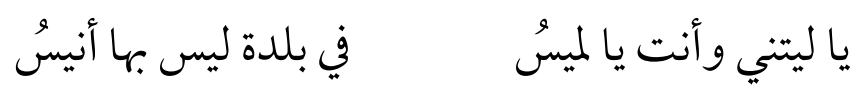

وهذا خطأ عند البصريين، يقول أبو حيان: ((وهذا خطأ عند البصريين، وهو لا يجوز عندهم في (إن)، فهو في ليت وكأن ولعل أبعد .. وتأولوا هذا البيت على أن التقدير: يا لينني وأنت معي، فحذف (معي)، وهو خبر (أنت)، والجملة حالية واقعة بين اسم (ليت) وخبرها ))(107).

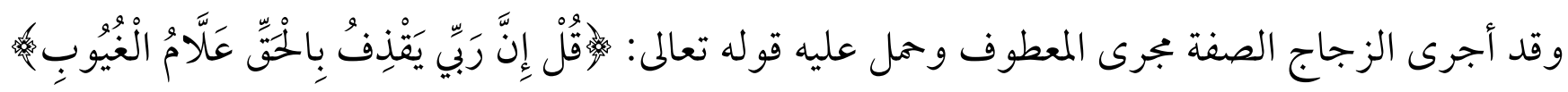
(سبأ: 48)، وأباه غيره. وإنما يصح الحمل على المحل بعد مضي الجملة فإن لم تمض لزمك أن تقول إن زيداً وعمراً قائمان بنصب عمرو ولا غير (108).

وأجاز الجرمي و الفراء رفع نعت الاسم بعد الخبر، وبمثل ذلك حكموا للتوكيد وعطف البيان، وأجازوا أن

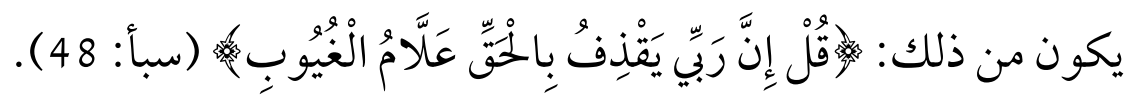
وأجاز الكسائي رفع المعطوف على أول مفعولي ظن إن خفي إعراب ثانيها، نحو: ظنتت زيدا صديقي وعمرّو (109). 


\section{المبحث الرابع : تابع اسهم لا النافية للجنس}

يقول سيبويه في باب وصف المنفي: ((اعلم أنك إذا وصفت المنفى فإن شئت نونت صفةً المنفى وهو أكثر في الكلام، وإن شئت لمُ تنون. وذلك قولك: لا غلام ظريفا لك، ولا غلامَ ظريفَ لك. فأما الذين نونوا فإنهم جعلو الاسم و لا بمنزلة اسم واحد، وجعلو اصفة المنصوب في هذا الموضع بمنزلته في غير النفي. وأما الذين قالو ا: لا غلامَظريفَ لك، فإنهم جعلوا الموصوف و الوصف بمنزلة اسم واحد)(110). فالأكثر عند سيبويه تنوين الصفة في هذا الموضع بجعل (لا) واسمها بمنزلة اسم واحد، يقول ابن مالك(111):

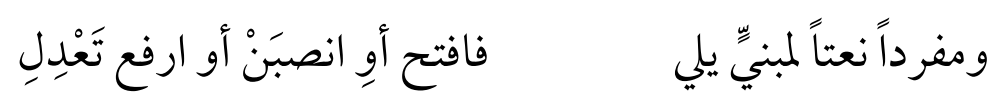

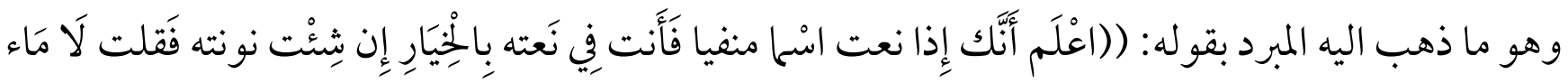

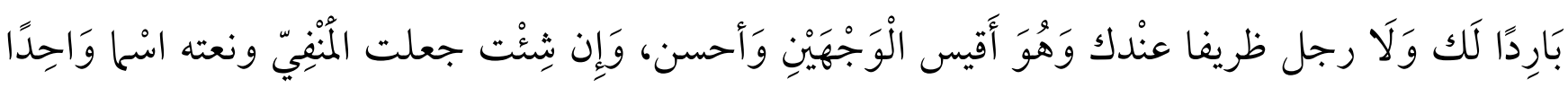
فَقَلت لَا رجل ظريف عنْدك وَلَا مَاء بَارِدِ لَك)()(112). فالمبرد يرى أن الأقيس والأحسن هو تنوين النعت، ويرى الزخشري أن في صفة المفردو وجهين: أحدها: أن يبنى معه على الفتح كقولك لا رجل ظريف فيها. والثاني: أن تعرب محموله على لفظه أو محله كقولك لا رجل ظريفاً فيها أو ظريف، وإن فصلت بينها أعربت. وليس في الصفة الزائدة عليها إلا الإعراب(113). وتنصب الصفة مراعاة لمحل النكرة المو صوفة؛ لأنها في محل نصب بــ(لا). ويرى الشاطبي أن النصب بالحمل على لفظ النكرة، وإن كان مبنيا؛ لأن حركة البناء هنا شبيهة بحركة الإعراب بل الإعراب أصلها(114). ويجوز رفعها مراعاة لمحلها مع (لا) لأنها في محل رفع بالابتداء لصيرورتها بالتركيب كشيء واحد، فحكموا على محلها بالرفع، وجعلو ا النعت للمجموع (115). وجاز الرفع بالنظر إلى المحل، و النصب بالنظر إلى لفظ المنعوت إن كان معربًا، وإلى محله إن كان مبنيا. 
يقول أبو حيان: (وتنصب صفة اسم (لا) أو تُرفع مطلقًا، وقد تُجعل مع الموصوف كـ (خمسة عشر) إن أُفردا

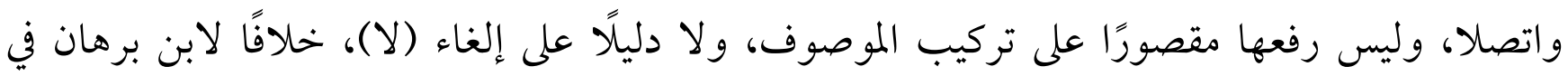

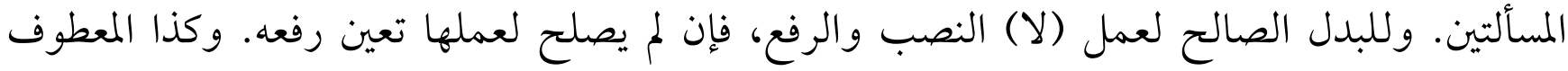

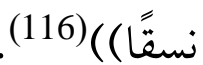

$$
\text { ذكر المرادي في توضيح المقاصد: أنه يجوز في نعت اسم (لا) المبني ثلاثة أوجه: }
$$

فتحه ونصبه، ورفعه بشرطين: أحدهما: أن يكون مفردا، والثاني: أن يتصل بالاسم، ولهذا قال ابن مالك: "يلي" أي: يلي المنعوت فتقول: لا رجل ظريف بالفتح على تركيب الصفة مع الموصوف وبالنصب اعتبارا لعمل (لا) وبالرفع اعتبار العمل الابتداء (117). فالبناء على أنه ركب الموصوف مع الصفة تركيب خمسة عشر، ثم دخلت (لا) عليها، و النصب على إتباع الصفة لمحل اسم (لا) والرفع على إتباعها لمحل (لا) مع اسمها (118). وإن فصل النعت عن اسم (لا) تعذر بناؤه على الفتح، لزوال التركيب بالفصل، وجاز فيه النصب نحو (لا رجل فيها ظريفا) والرفع أيضا نحو (لا رجل فيها ظريف)، وكذلك أن كان النعت غير مفرد تقول: لا رجل

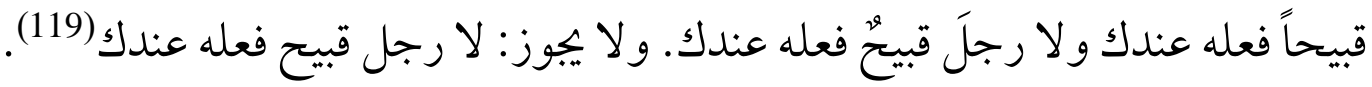
فإن لم يكن اسم (لا) مبنيا تعذر بناء الصفة أيضا وجاز فيها وجهان: الرفع والنصب تقول: لا صاحب بر بر سيع مقوتُّ أو مقوتًا. يقول المرادي: ((فإن قلت: هذا حكم نعت المبنياً فما حكم نعت المعرب؟قلت: فيه وجهان: الرفع والنصب مطلقا، وقد وهم من منع الرفع)(120(1).

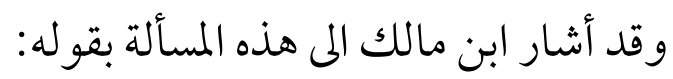

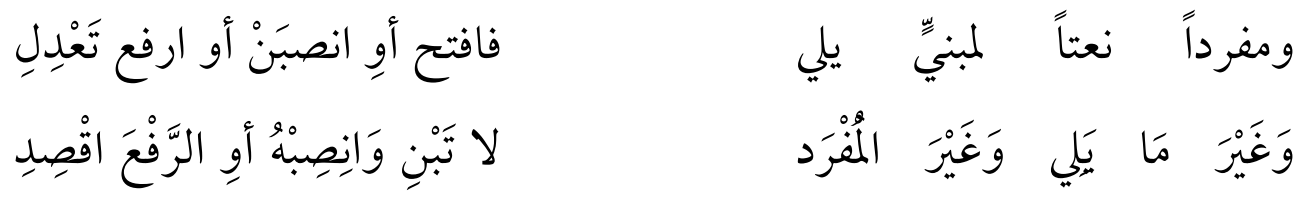
وأما العطف فيرى الزخشري أن حكم المعطوف حكم الصفة إلا في البناء(121). 
يقول ابن يعيش: ((حكمُ المعطوف كحكم الصفة لأنّها) من التوابع، إلَّا في البناء، فإنّه لاييوز بناءُ المعطوف،

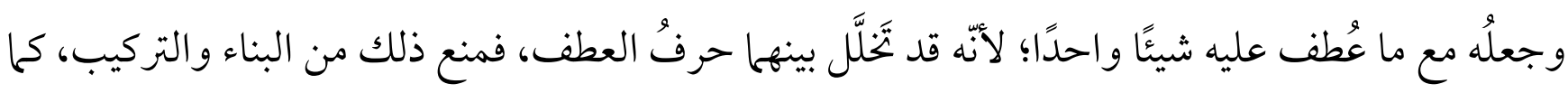

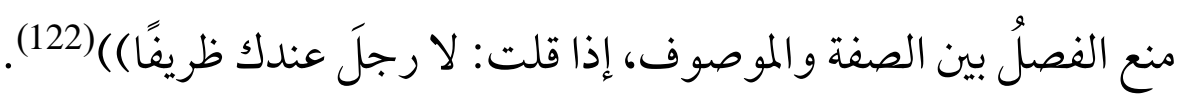

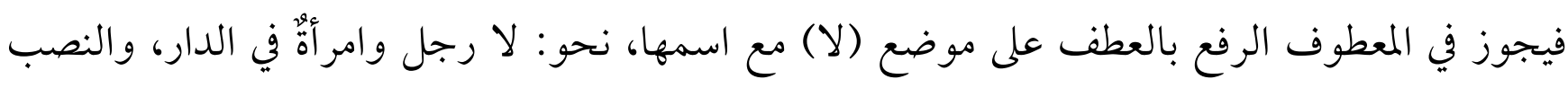
بالعطف على موضع اسم (لا) نحو: لا رجل وامر أةًَ في الدار (123)، قال الشاعر (124):

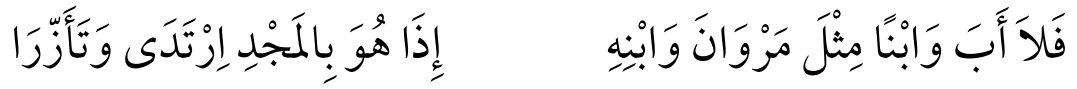

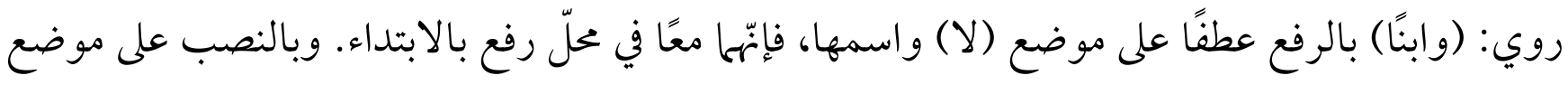
اسمها باعتبار عملها (125.)

إذا عطف على اسم (لا) بدون تكر ارها امتنع إلغاء (لا) وجاز في المعطوف الرفع بالعطف على موضع (لا) مع

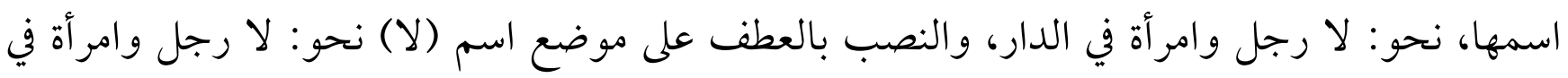

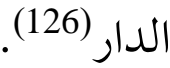

ومن المسائل التي عرضها النحويون هي هل يهوز العطف على الموضع قبل الخبر أو لا ييوز، يقول ناظر

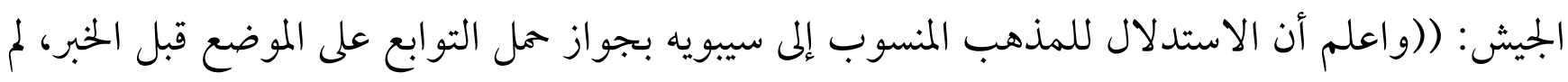
يظهر لي وجه صحته، فإن حمل التابع على الموضع جائز قبل الخبر، إذا كان اسم (لالا) غير مركب معها أيضا، ولا شك أن (لالا) عاملة حينذ في الخبر إجماعا، فدل ذلك على أن حمل التوابع على الموضع قبل الخبر، لا أثر له له

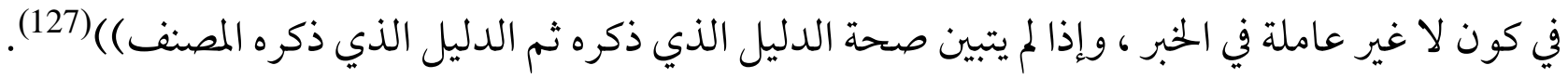

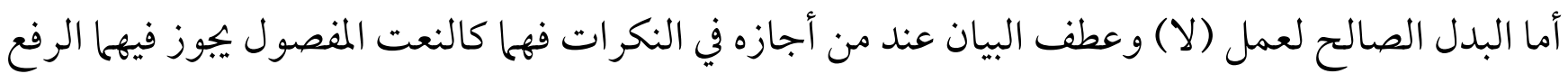
والنصب؛ فإن كان البدل معرفة تعين رفعه إذ المعرفة لا تصلح لعمل (لا). و وأما التوكيد فقيل لا يدخل في هذا الباب لأن النكرة لا تؤكد. وإنما يمتنع توكيد النكرة عند البصريين بالتوكيد المعنوي، وأما اللفظي فلا يمتنع (128). 


\section{خاتهـة}

بعد دراسة مسألة خلافية من مسائل النحو ، يمكنني أن أجمل أهم النتائج التي توصل اليها البحث بالاتي : 1 - جواز الاتباع على المحل من المسائل الخلافية التي تعددت حولها الآراء والاقوال. 2 - ذهب البصريون ومنهم سيبويه الم عدم جواز الاتباع على المحل. 3 - ذهب الكوفيون وطائفة من البصريين الى جواز الاتباع على المحل. 4 - جوز بعض النحويين الاتباع على المحل في العطف و البدل ومنعو الاتباع في التوكيد والنعت. 5 - تابع المنادى المبني يتبع في اللفظ ويتبع في المحل ، وكل تابع له حكمه النحوي. 6 - ذهب الأخفش المى أن تابع المنادى العلم المبني على الضم لا يكون الا منصوبا على المحل ولا يتبع في اللفظ.

7 - ذهب بعضهم الى أن تابع المنادى المبني اذا كان نعتا فأنه يكون مبنيا. 8 - اختلف النحويون في العطف على محل اسم إن ، وفرقوا بينها وبين أخو اتها. وختاما أسأل الله تعالى توفيقه ، و الحمد لله في الأولى والاخرة ........

\section{المصادر والمراجع}

1. إتحاف فضلاء البشر في القراءات الأربعة عشر ،أحمد بن محمد الدمياطي(ت 1117هـ) تحقيق: أنس مهرة ، دار الكتب العلمية -

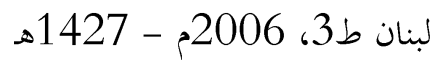

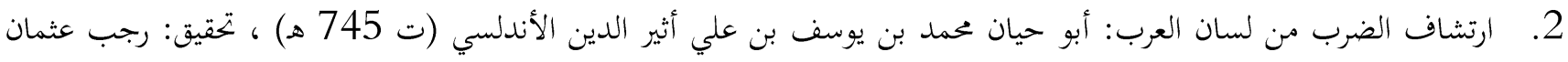

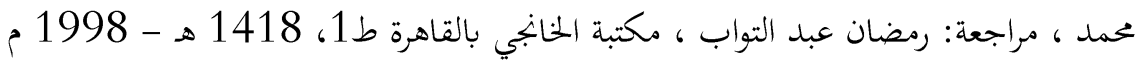

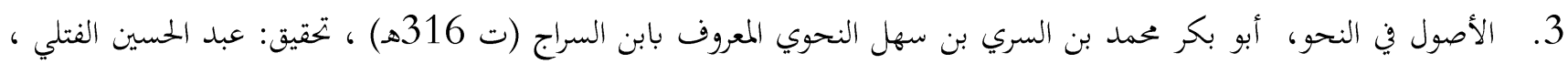

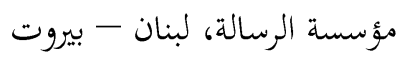

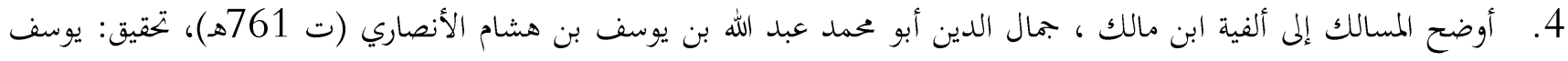

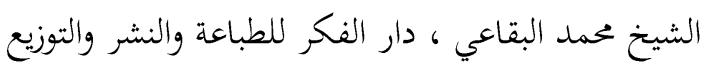
5. البحر المخيط في التفسير، أبو حيان محمد بن يوسف بن علي ألثير الدين الأندلسي (ت 745هـ) ، تحقيق: صدقي محمد جميل ،دار

$$
\text { الفكر بيروت ، } 1420 \text { هـ }
$$


6. تاج العروس من جواهر القاموس ، محمد بن محمد بن عبد الرزاق الحسيني، أبو الفيض، الملقّب بمرتضى، الزّبّدي (ت 1205هـ)،

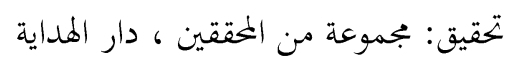

7. تخليص الشواهد وتلخيص الفوائد ، جمال الدين أبو محمد عبد الله بن يوسف بن هشام الأنصاري (ت: 761 هـ) ،تحقيق: د. عباس

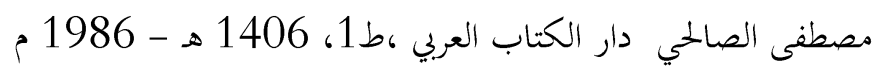

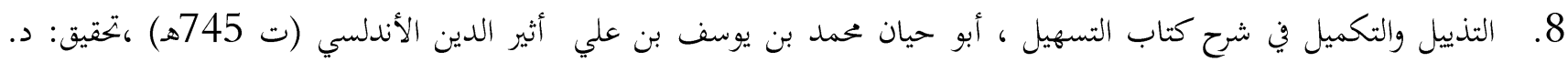

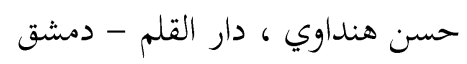

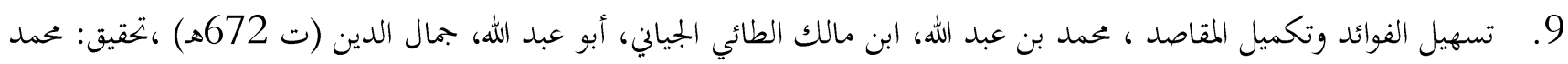

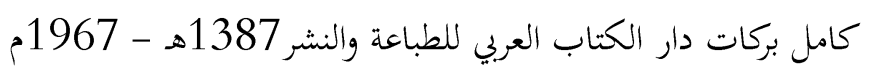

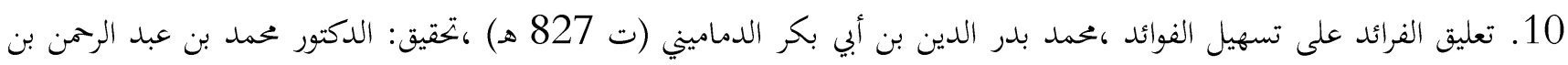

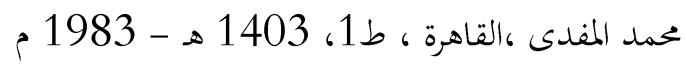

11. التعليقة على كتاب سيبويه: الحسن بن أحمد بن عبد عبد الغنفار ، أبو علي الفارسي (ت: 377هـ) ، تحقيق: د. عوض بن حمد القوزي

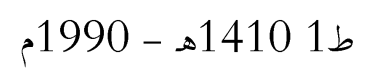

12. تحذيب اللغة، محمد بن أمد بن الأزهري المروي، أبو منصور (ت 370هـ) ، تحقيق: محمد عوض مرعب ، دار إحياء التراث العربي -

$$
\text { بيروت ط1، 2001م }
$$

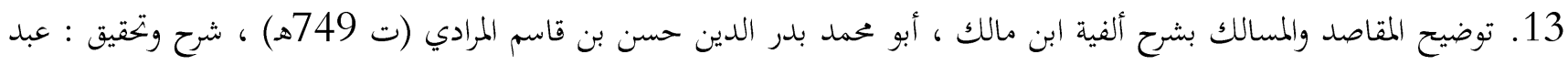

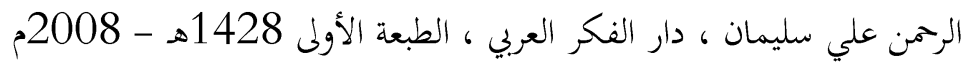

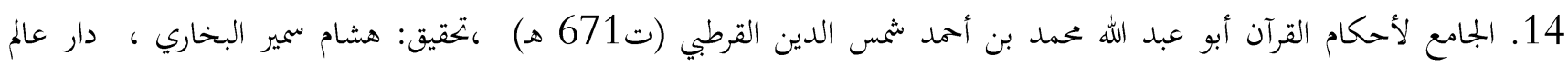

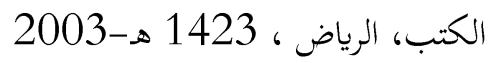

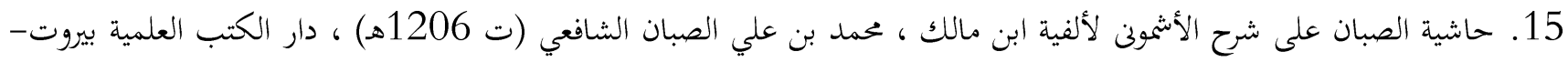

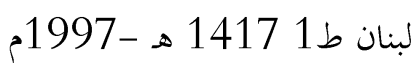

16. خزانة الأدب ولب لباب لسان العرب،عبد القادر بن عمر البغدادي (ت 1093هـ) ،تحقيق: عبد السلام محمد هارون ،مكتبة

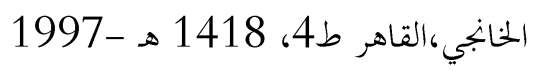

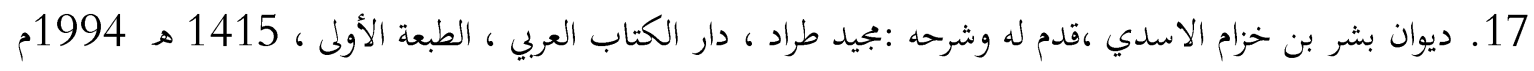

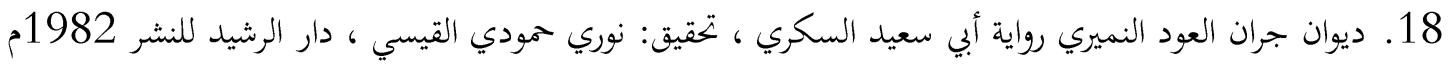

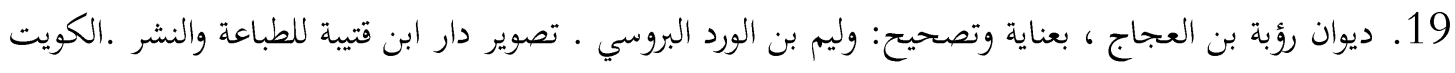

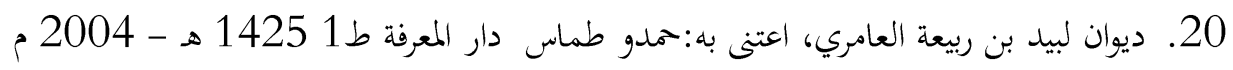

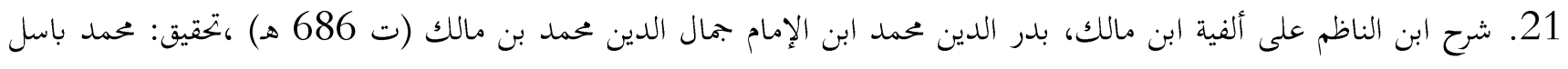

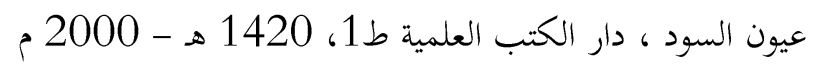

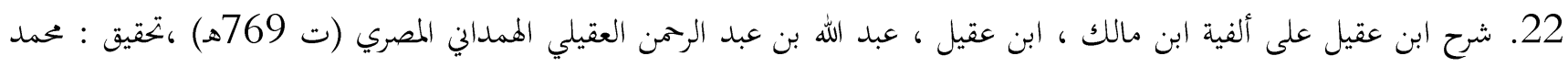

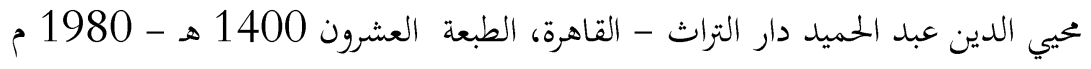


23. شرح أبيات سيبويه ، يوسف بن أبي سعيد الحسن بن عبد الله بن المرزبان أبو محمد السيرافي (ت 385ه) ، تحقيق : الدكتور محمد

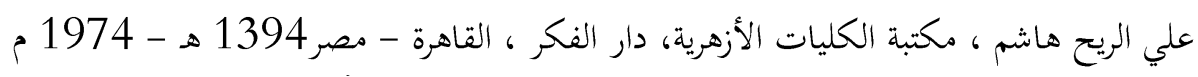

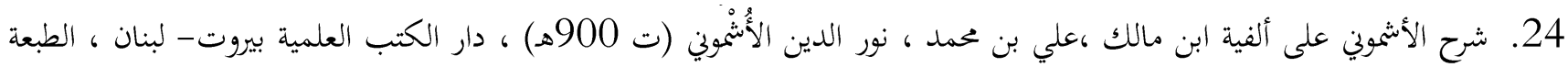

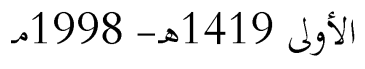

25. تمهيد القواعد بشرح تسهيل الفوائد، محمد بن يوسف بن أحمد، محب الدين الحلبي، المعروف بناظر الجيش (ت 778 هـ) ،دراسة

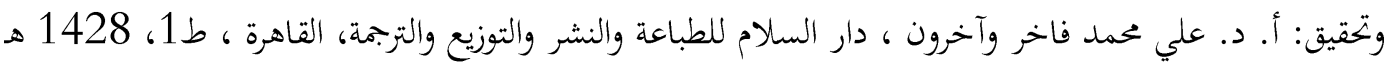

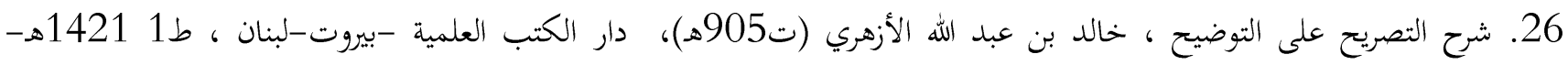
2000

27. شرح الرضي على الكافية ،رضي الدين الأستراباذي ( ت 686هـ) ، تصحيح وتعليق: يوسف حسن عمر ، جامعة قاريونس 1398 هـ 1978 هـ

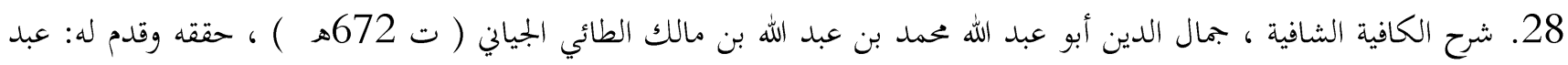

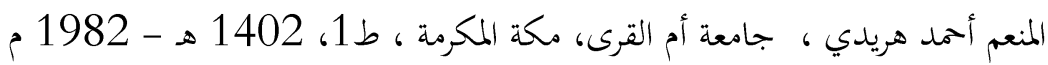

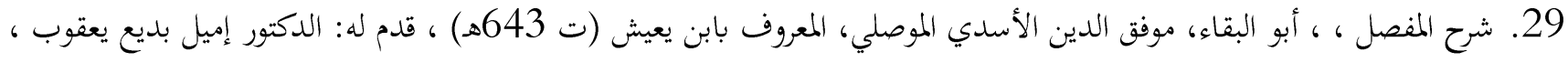

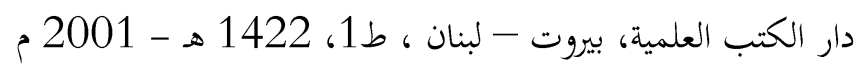

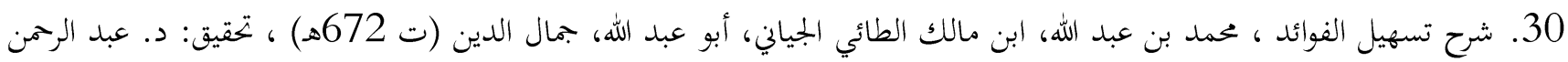

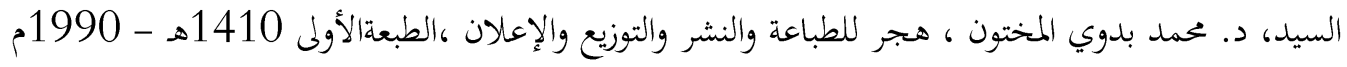

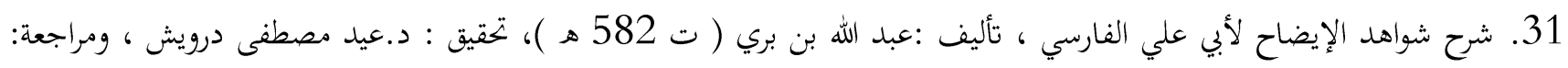

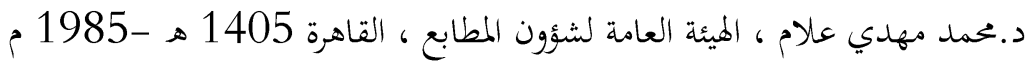

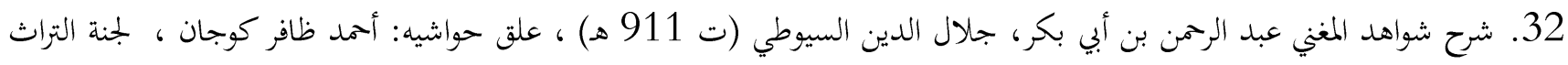

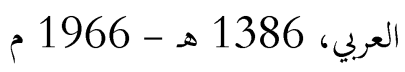

33. شرح كتاب سيبويه، أبو سعيد السيرافي الحسن بن عبد الله بن المرزبان (ت 368 هـ) ، تحقيق: أحمد حسن مهدلي، علي سيد علي ،

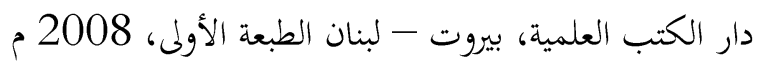

34. صحيح مسلم ، مسلم بن الحجاج أبو الحسن القشيري النيسابوري (ت: 261هـ) ، تحقيق: محمد فؤاد عبد الباقي ، دار إحياء التراث

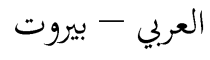

35. الكتاب ، عمرو بن عثمان بن قنبر الحارثي بالولاء، أبو بشر، الملقب سيبويه (ت 180هـ) ،تحقيق: عبد السلام محمد هارون ، مكتبة

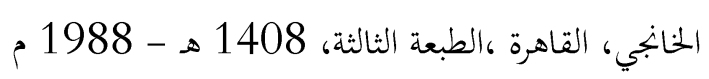

36. كتاب التعريفات ،علي بن محمد بن علي الزين الشريف الجرجاني (ت 816هـ) تحقيق: ضبطه وصححه جماعة من العلماء، دار

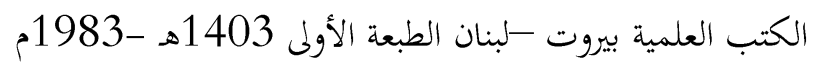

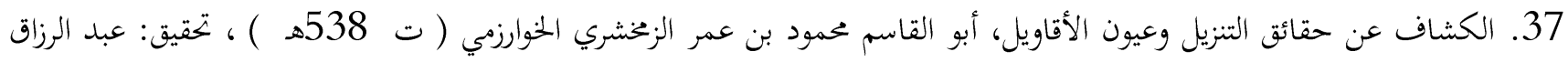

$$
\text { المهدي ،دار إحياء التراث العربي - بيروت }
$$


38. لسان العرب ، محمد بن مكرم ، أبو الفضل، جمال الدين ابن منظور الأنصاري الإفريقى (ت 711هـ) ، دار صادر - بيروت، الطبعة

الثالثة - 1414 هـ

39. اللمع في العربية أبو الفتح عثمان بن جني الموصلي (ت 392هـ) ،تحقيق: فائز فارس، دار الكتب الثقافية - الكويت

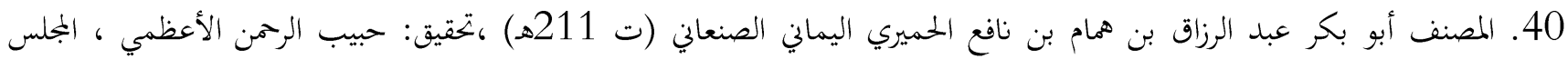

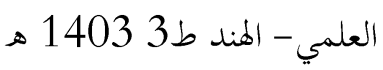

41. مشكل إعراب القرآن أبو محمد مكي بن أبي طالب القيسي (ت 437 4هـ) تحقيق: د. حاتم صالح الضامن مؤسسة الرسالة - بيروت

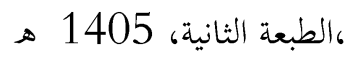

42. معاني القرآن أبو زكريا يميى بن زياد الفراء (ت 207هـ) ، تنقيق: أحمد يوسف النجاتي ، ومحمد علي النجار وعبد الفتاح إسماعيل

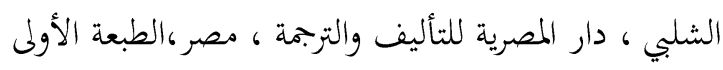

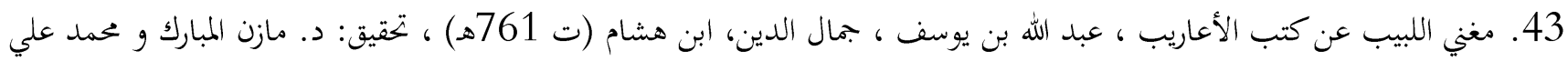

حمد الله ، دار الفكر - دمشق ، ط6ابك، 1985

44. مفاتيح الغيب (التفسير الكبير)، أبو عبد الله محمد بن عمر بهن الفهر الحسن الملقب بفخر الدين الرازي (ت 606هـ) ،دار إحياء التراث

$$
\text { العربي - بيروت ط3 } 1420 \text { هـ }
$$

45. المفصل في صنعة الإعراب، أبو القاسم حممود بن عمرو بن أمد، الزخشري جار الله (ت 538هـ) ، تحقيق: د. علي بو ملحم ،مكتبة

الهلال بيروت ط1، 1993

46. المقاصد الشافية في شرح الخلاصة الكافية، أبو إسحق إبراهيم بن موسى الشاطبي (ت 790 هـ) ، تحقيق : د. عبد الرمالمن بن سليمان

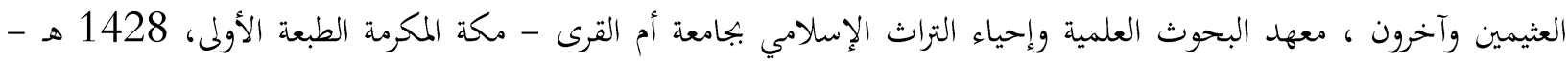
2007

47. المقاصد النحوية في شرح شواهد شروح الألفية ،بدر الدين محمود بن أحمد العيني (ت 855 هـ) ،تحقيق: أ. د. علي محمد فاخر،

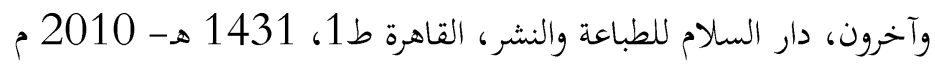

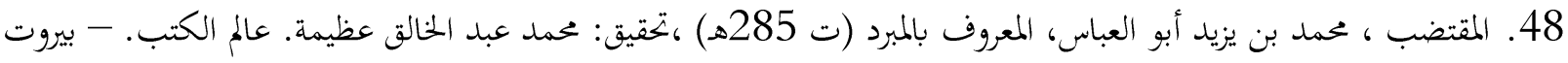

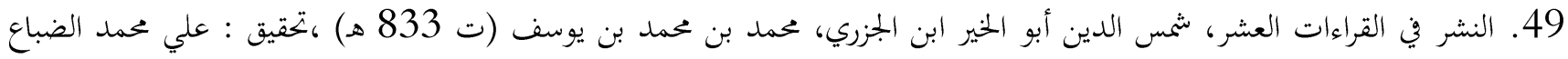

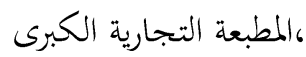
50. همع الموامع في شرح جمع الجوامع ، عبد الرمن بن أبي بكر، جلال الدين السيوطي (ت 911هـ) ، تحقيق: عبد الحميد هنداوي، المكتبة التوفيقية - مصر. 


$$
\begin{aligned}
& \text { هوامش البححث } \\
& \text { (1) تاج العروس 20/ } 372
\end{aligned}
$$

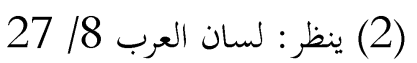

$$
\begin{aligned}
& 218 \text { / } 212 \text { (3) شرح المفصل لابن يعيش : (2) }
\end{aligned}
$$

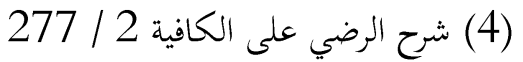

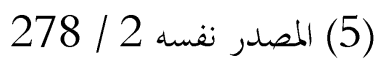

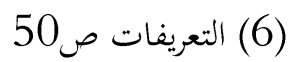

$$
\begin{aligned}
& 125 \text { / } 123 \text { (7) مصنف عبد الرزاق }
\end{aligned}
$$

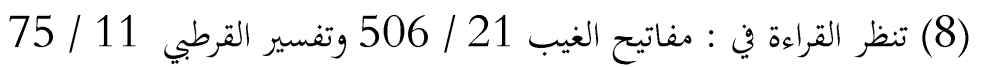

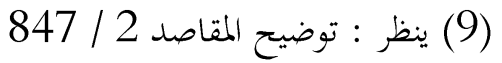

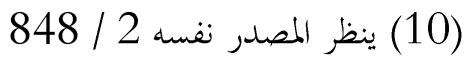

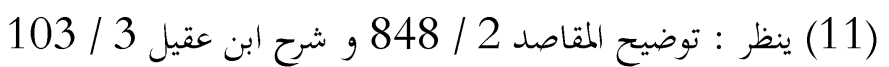

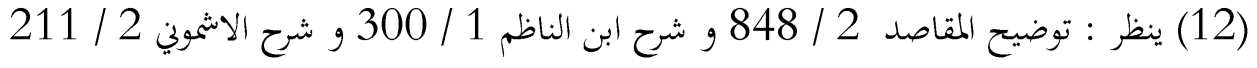

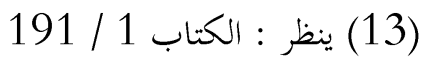

$$
\begin{aligned}
& \text { (14) ينظر : توضيح المقاصد } 2 \text { / } 848 \text { وشئرح الاشموني } 2 \text { / } 213 \text { / } 262 \text { وشرح التصريح } 2 \text { / } 10 \text { وحاشية الصبان } 2 \text { / } 439 \text { وارتشاف الضرب } \\
& 2262 \text { / } 5 \\
& 128 \text { (15) البيت للشاعر لبيد بن ربيعة العامري ، ينظر : ديوانه } \\
& 179 \text { / } 13 \text { (16) }
\end{aligned}
$$

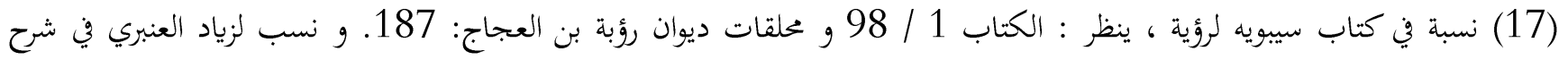

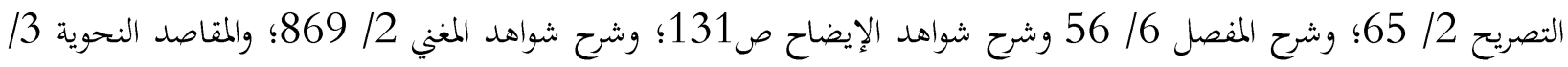

$$
\begin{aligned}
& \text { 520؛ وبلا نسبة في خزانة الأدب 5/ } 102 \text { الأدل } 102 \\
& 180 \text { / } 180 \text { (18) } \\
& \text { (19) نسب للمتنخل الهذلي في خزانة الأدب 5/ 11؛ و نسب في تخذيب اللغة لتأبط شرا "11/ } 166
\end{aligned}
$$

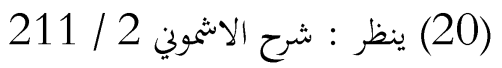

$$
\begin{aligned}
& \text { (21) ينظر : توضيح المقاصد } 13 \text { (213. }
\end{aligned}
$$

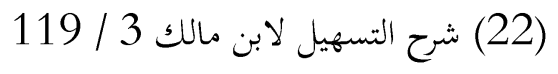

$$
\begin{aligned}
& 2851 \text { / } 28 \text { ينظر : متهيد القواعد التهيل }
\end{aligned}
$$


190 / 190 (25) ينظر : الجامع لاحكام القران للقرطبي

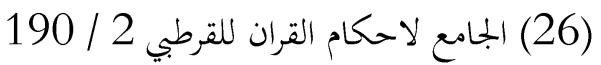

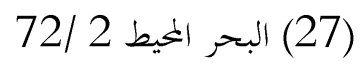

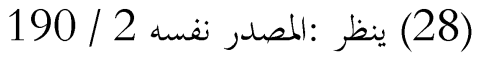

72 / 72 (29) البحر الخيط :لمطيد

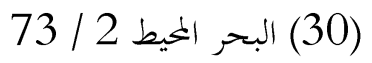

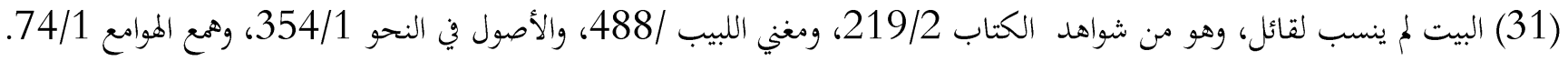

45 / 45 (32) ينظر :شرح أبيات سيبوين

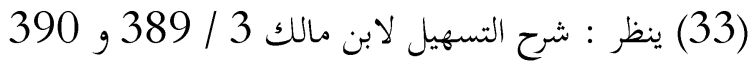

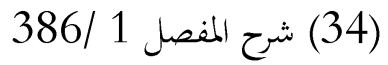

(35) لم ينسب لقائل، وهو من شواهد شرح التسهيل لابن مالك 120/1، 135، وتمهيد القواعد 6 / 2852، والتذييل والتكميل 95/11.

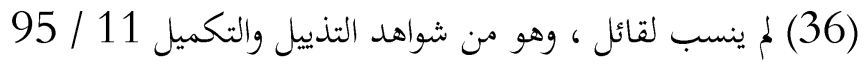

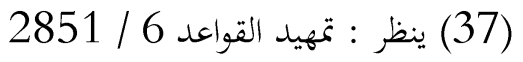

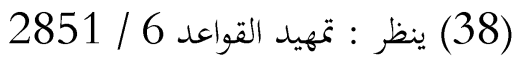

2851 / 6 (39) ينظر :المصدر نفسرال

2852 / 28 (40)

(41) مر تخريجه

(42) مر تخريجه

121 / 12 (43) شرح التسهيل لابن مالكه

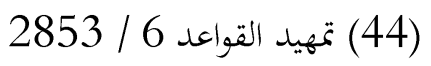

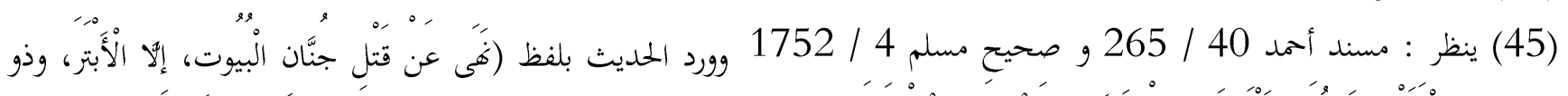

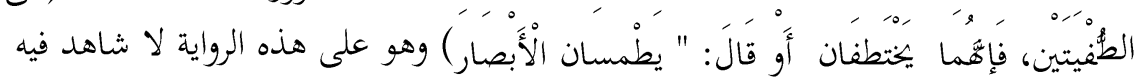

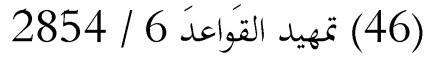

92 / 911 (47) التذييل والتكميل

93 / 9311 ينظر : التذييل والتكميل

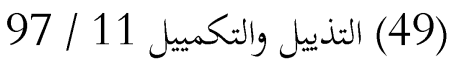

97 / 11 (50) المصدر نفسي

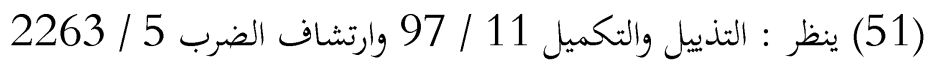

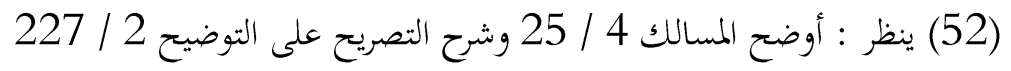




$$
\begin{aligned}
& 26 \text { / } 4 \text { (53) }
\end{aligned}
$$

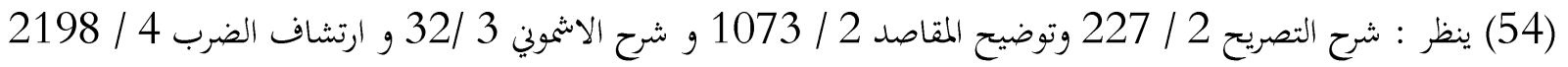

$$
\begin{aligned}
& 1073 \text { / } 2 \text { / } 2 \text { ينظر :توضيح المقاصر }
\end{aligned}
$$

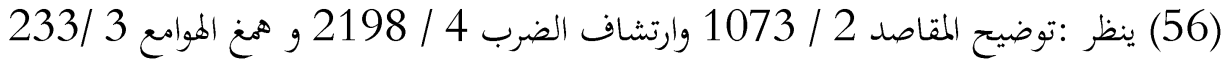

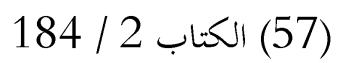

$$
\begin{aligned}
& \text { (58) ينظر :التعليقة على كتاب سيبويه } 1 \text { / } 329 \\
& \text { (59) ينظر : شرح التصريح } 2 \text { / } 227 \text { (50) } \\
& 1311 \text { / } 131 \text { (60) } \\
& 1311 \text { / } 131 \text { (61) ينظر : شرح الكافية الشافية } 13 \text { (60) }
\end{aligned}
$$

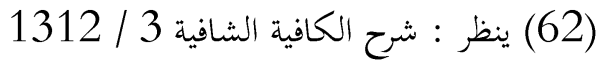

$$
\begin{aligned}
& \text { (63) ينظر : المقتضب } 4 \text { / } 209
\end{aligned}
$$

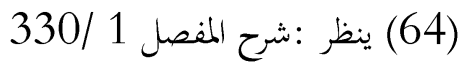

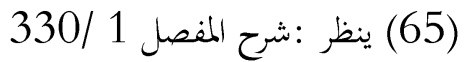

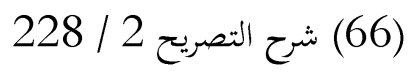

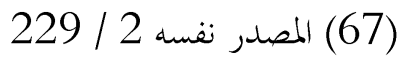

$$
\begin{aligned}
& 229 \text { / } 22 \text { (68) المصدر نفسن (6) }
\end{aligned}
$$

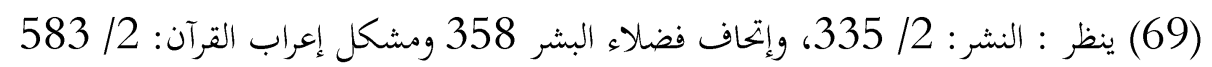

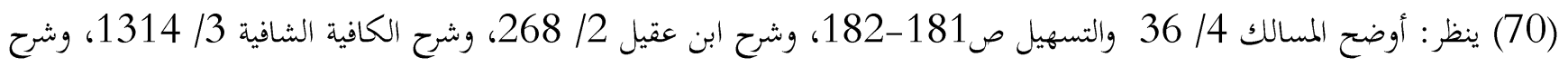

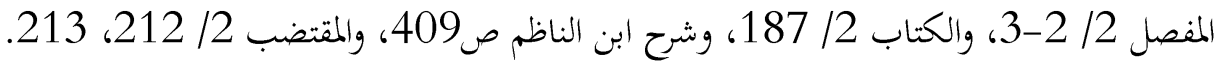

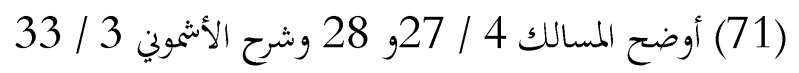

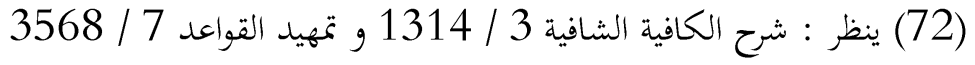

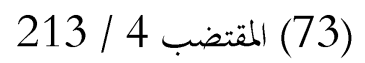

$$
\begin{aligned}
& \text { (74) ينظر :ارتشاف الضرب } 4 \text { / } 2199 \\
& \text { (75) ينظر :المصدر نفسه } 4 \text { / } 4199 \\
& \text { (76) ينظر :ارتشاف الضرب } 4 \text { / } 2199 \\
& 230 \text { / } 2 \text { / (77) } \\
& 28 \text { / } 28 \text { (78) أوضح المسالك }
\end{aligned}
$$

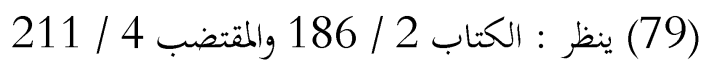

$$
\begin{aligned}
& \text { (80) ينظر :شرح الاشموني } 3 \text { / } 32 \text { و شرح التصريح } 2 \text { / } 231 \text { / 231 و حاشية الصبان } 3 \text { / } 220
\end{aligned}
$$




$$
\begin{aligned}
& 402 \text { / } 3 \text { (81) } \\
& 402 \text { / } 3 \text { (82) ينظر :المصدر نفسرحس (82) }
\end{aligned}
$$

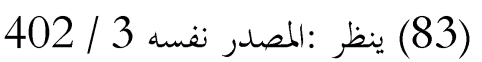

$$
\begin{aligned}
& \text { (84) ينظر : كتاب سيبويه } 2 \text { / } 144 \text { والأصول في النحو } 1 \text { / } 240 \text { وشرح التسهيل لابن مالك } 2 \text { / } 248 \text { / } 24 \\
& 144 \text { / } 14 \text { ينظر : كتاب سيبوين } \\
& \text { (86) ينسب لجرير وليس في ديوانه، وهو من شواهد الكتاب 145/2 145، والمقاصد النحوية 2/ 263، وشرح التسهيل لابن مالك } 2 \text { الك } \\
& 393 \text { ينظر : (87) } \\
& 473 \text { / } 478 \text { (88) } \\
& 48 \text { / } 48 \text { (89) } \\
& \text { (90) البيت بلا نسبة في تخليص الشواهد ص370 وشرح التصريح } 1 \text { / } 227 \text { والمقاصد النحوية 2/ } 265 \text { وهمع الهوامع } 2144
\end{aligned}
$$

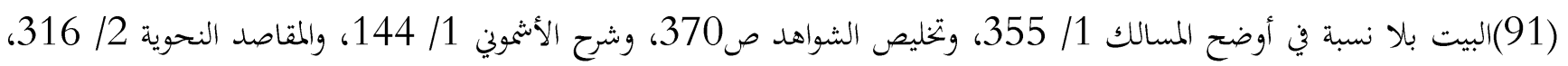

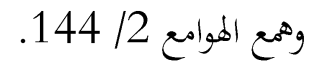

$$
\begin{aligned}
& 48 \text { / } 4 \text { / } 2 \text { (92) }
\end{aligned}
$$

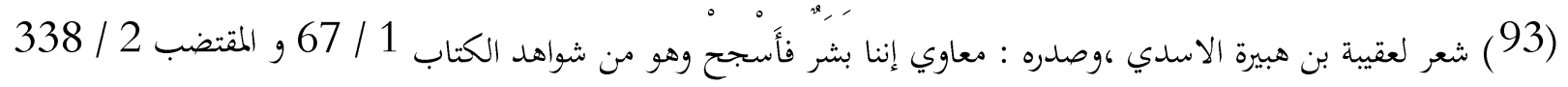

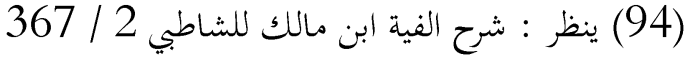

$$
\begin{aligned}
& 49 \text { / 2: (95) ينظر شرح التسهيل } \\
& 116 \text { (96) ينظر : ديوانه صنئرح } \\
& 51 \text { / } 51 \text { ينظر : شرح التسهيل }
\end{aligned}
$$

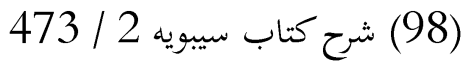

$$
\begin{aligned}
& 51 \text { / } 51 \text { (99) } \\
& 146 \text { / } 142 \text { (100) } \\
& 144 \text { / } 142 \text { (101) } \\
& 474 \text { / } 4 \text { / (102) } \\
& 111 \text { / } 4 \text { (103) } \\
& 541 \text { / } 4 \text { ينظر : شرح المفصل }
\end{aligned}
$$

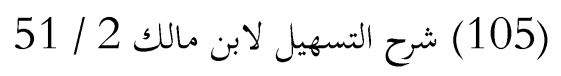

$$
\begin{aligned}
& \text { (107) التذييل والتكميل } 5 \text { / } 207 \text { ، وينظر شرح التسهيل لابن مالك } 2 \text { / / } 52
\end{aligned}
$$




$$
\begin{aligned}
& \text { (108) ينظر المفصل } 393
\end{aligned}
$$

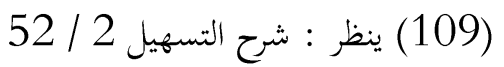

$$
\begin{aligned}
& 289 \text { / } 2 \text { / (110) } \\
& \text { (111) ينظر : شرح ابن عقيل } 2 \text { / } 16
\end{aligned}
$$

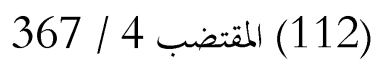

$$
\begin{aligned}
& 108 \text { (113) ينظر : المفصل }
\end{aligned}
$$

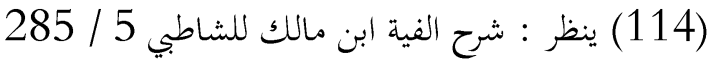

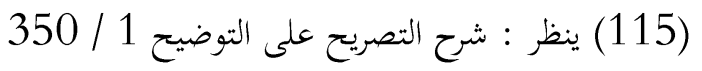

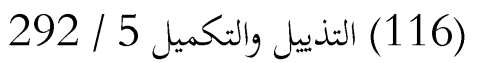

$$
\begin{aligned}
& 548 \text { / } 54 \text { (117) توضيح المقاصد } 1117
\end{aligned}
$$

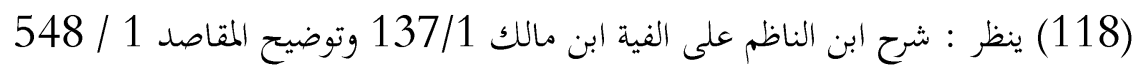

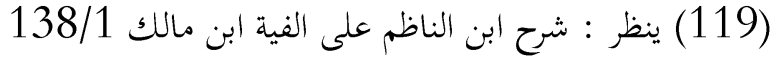

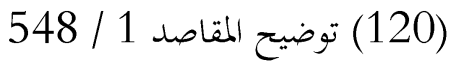

$$
\begin{aligned}
& 108 \text { (121) } \\
& 109 \text { / 122 (123) شرح المفصل } 1 \text { (123) } \\
& \text { (123) ينظر : شرح ابن الناظم على ألفية ابن مالك } 1 \text { / / } 138
\end{aligned}
$$

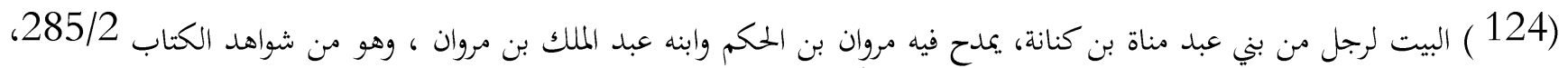

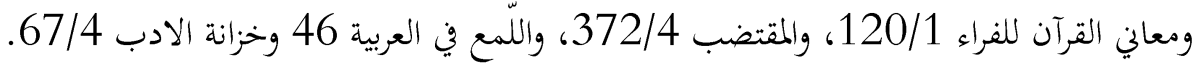

$$
\begin{aligned}
& \text { (125) تعليق الفرائد } 4 \text { / } 121 \text { ، وتوضيح المقاصد 126 } 1 \text { / } 1248 \text { المنفي }
\end{aligned}
$$

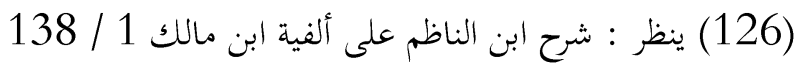

$$
\begin{aligned}
& \text { (127) ينظر : تمهيد القواعد } 3 \text { / } 1422 \text { (128) }
\end{aligned}
$$

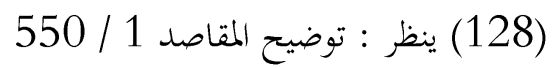

